Article

\title{
Synthesis, Antiproliferative, and Antioxidant Evaluation of 2-Pentylquinazolin-4(3H)-one(thione) Derivatives with DFT Study
}

\author{
Amira A. El-Sayed ${ }^{1}$, Mahmoud F. Ismail ${ }^{1}{ }^{1}$, Abd El-Galil E. Amr ${ }^{2,3, *(1)}$ and \\ Ahmed M. Naglah ${ }^{2,4}$ (D) \\ 1 Department of Chemistry, Faculty of Science, Ain Shams University, 11566 Abbassia, Cairo 11566, Egypt; \\ amira_aa47@hotmail.com (A.A.E.-S.); fawzy2010@sci.asu.edu.eg (M.F.I.) \\ 2 Pharmaceutical Chemistry Department, Drug Exploration \& Development Chair (DEDC), \\ College of Pharmacy, King Saud University, Riyadh 11451, Saudi Arabia; amnaglah@gmail.com \\ 3 Applied Organic Chemistry Department, National Research Center, Cairo, Dokki 12622, Egypt \\ 4 Peptide Chemistry Department, Chemical Industries Research Division, National Research Centre, Dokki, \\ Cairo 12622, Egypt \\ * Correspondence: aamr@ksu.edu.sa; Tel.: +966-543074312
}

Academic Editor: Qiao-Hong Chen

Received: 5 October 2019; Accepted: 20 October 2019; Published: 21 October 2019

check for updates

\begin{abstract}
The current study was chiefly designed to examine the antiproliferative and antioxidant activities of some novel quinazolinone(thione) derivatives 6-14. The present work focused on two main points; firstly, comparing between quinazolinone and quinazolinthione derivatives. Whereas, antiproliferative (against two cell lines namely, HepG2 and MCF-7) and antioxidant (by two methods; ABTS and DPPH) activities of the investigated compounds, the best quinazolinthione derivatives were $\mathbf{6}$ and 14, which exhibited excellent potencies comparable to quinazolinone derivatives $\mathbf{5}$ and $\mathbf{9}$, respectively. Secondly, we compared the activity of four series of Schiff bases which included the quinazolinone moiety (11a-d). In addition, the antiproliferative and antioxidant activities of the compounds with various aryl aldehyde hydrazone derivatives (11a-d) analogs were studied. The compounds exhibited potency that increased with increasing electron donating group in $p$-position $(\mathrm{OH}>\mathrm{OMe}>\mathrm{Cl})$ due to extended conjugated systems. Noteworthy, most of antiproliferative and antioxidant activities results for the tested compounds are consistent with the DFT calculations.
\end{abstract}

Keywords: quinazolin-4(3H)-one; quinazolin-4(3H)-thione; Schiff base; antiproliferative activity; antioxidant activity; DFT study

\section{Introduction}

Cancer is the second leading cause of death globally, and the contribution of cancer disease to the overall mortality rate is increasing. Economically, the total annual cost of cancer in 2010 was estimated at approximately US\$ 1.16 trillion [1]. So that, more rational design, synthesis, and evaluation of new compounds as anticancer, with higher efficiency is considered as urgent mission in the medicinal chemistry field.

Quinazoline and quinazolinone derivatives are considered as tremendous targets for the medicinal chemists, due to the fact that they are the scaffold of different potent anticancer drugs, such as Gefitinib (trade name Iressa ${ }^{\circledR}$ ), Erlotinib (trade name Tarceva ${ }^{\circledR}$ ) [2-4], Methaqualone [5], Afloqualone (as anticonvulsant activity) [6,7], Chloroqualone (as antitussive), and Diproqualone (as sedative-hypnotic agents) [8] (Figure 1). 


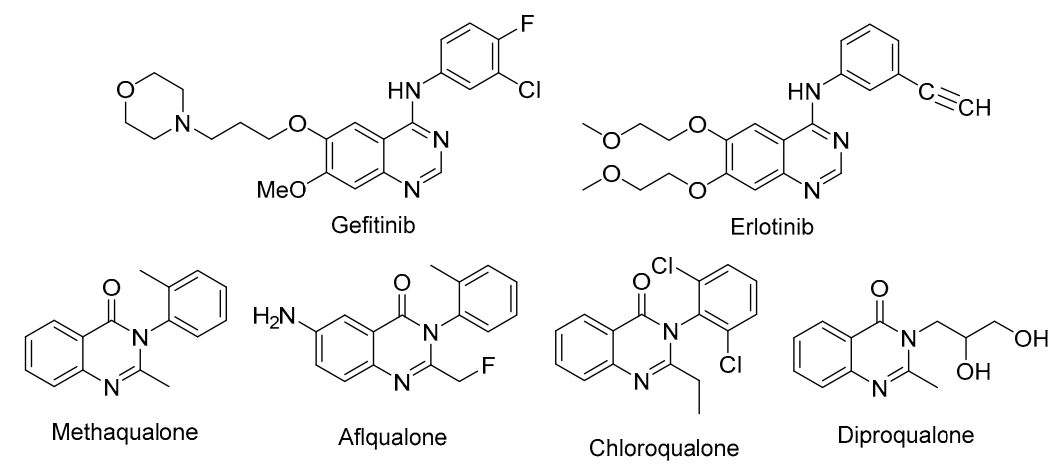

Figure 1. Some structures of synthetic drugs scaffold quinazoline and quinazolinone derivatives.

In the last decades and until now, various compounds including quinazolinone moiety conspicuously exhibited broad spectrum in numerous pharmacological activities such as anticancer [9-14], anticonvulsants [15], antiproliferative [16], anti-inflammatory [17], antihypertensive [18], antifungal [19], antibacterial, antioxidant [20], antimicrobial [21], anti-allergic [22], antimalarial [23], antileishmanial [24], and treatment of Alzheimer's disease (AD) [25].

Generally, the natural products are considered as one of the most interesting sources of biologically active compounds. Among them, naturally occurring quinazolin-4(3H)-one derivatives, which can be isolated from various plants and microorganisms such as Luotonin A (sources; Peganum nigellastrum) [26], 2-(heptan-3-yl)quinazolinone (sources; Bacillus cereus) [27], Dictyoquinazol A (sources; Dictyophora indusiata) [28], and Echinozolinone (sources; Echinops echinatus) [29] (Figure 2).<smiles>O=c1c2ccccc2nc2n1Cc1cc3ccccc3nc1-2</smiles>

Luotonin A<smiles>CCC(CC)c1nc2ccccc2c(=O)[nH]1</smiles>

2-(pentan-3-yl)quinazolinone<smiles>COc1ccc(-n2cnc3ccc(OC)cc3c2=O)c(C)c1</smiles>

Dictyoquinazol A<smiles>O=c1c2ccccc2ncn1CCO</smiles>

Echinozolinone

Figure 2. Some structures of naturally occurring quinazolin-4(3H)-one derivatives.

Quinazolinones have been synthesized by different methodologies [28,30-37], in the present study, the conventional methodology to construct novel qunizolinone compounds has been adopted, followed by the study of the antiproliferative activity, antioxidant activity, and DFT calculations for the synthesized compounds.

\section{Results and Discussion}

\subsection{Chemistry}

In this interesting work, curing of anthranilic acid $\mathbf{1}$ with hexanoyl chloride $\mathbf{2}$ in dry pyridine afforded the corresponding $N$-hexanoyl derivative 3 [38], which was cyclized by heating in distilled acetic anhydride to give 2-pentyl-4H-benzo[d][1,3]oxazin-4-one $4[39,40]$ (Scheme 1).

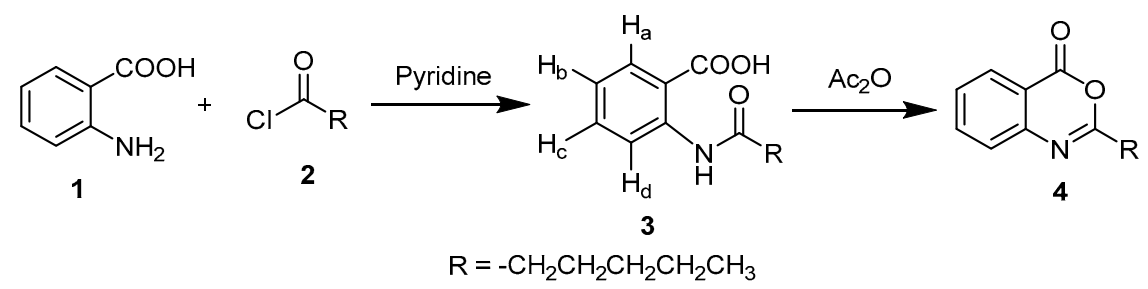

Scheme 1. The strategy for synthesis of compound 4 . 
Benzoxazinone derivative 4 was utilized in situ as a precursor to construct new quinazolinone derivatives. For instance, reaction of benzoxazinone derivative 4 with formamide afforded 2-pentylquinazolin-4(3H)-one 5 [41] (Scheme 2). The ${ }^{1} \mathrm{H}$ NMR spectrum of 5 exhibited a singlet peak at $12.13 \mathrm{ppm}$ exchangeable with $\mathrm{D}_{2} \mathrm{O}$ corresponding to $\mathrm{NH}$ proton, two doublet and two triplet peaks in the aromatic region at 8.05-7.42 ppm corresponding to four aromatic protons, and four characteristic peaks upfield at $2.56-0.84 \mathrm{ppm}$ for $n$-pentyl protons.

Afterwards, sulfuration of 2-pentylquinazolin-4(3H)-one 5 by utilizing of phosphorus pentasulfide in dry toluene afforded 2-pentylquinazoline-4(3H)-thione 6 (Scheme 2). The formation of compound 6 was unambiguously elaborated by the presence of intense band at $1236 \mathrm{~cm}^{-1}$ corresponding to $v c=s$ and the absence of the stretching band of $v c=0$ in the IR spectrum. On the other hand, the incorporation of $\beta$-D-glucose pentaacetate with quinazolinone derivative 5 at the nitrogen atom of the later awarded $N$-( $\beta$-D-glucopyranosyl-2,3,4,6-tetraacetate)-2-pentyl quinazolin-4(3H)-one 7 (Scheme 2), via attacking of the lone pair of nitrogen atom of quinazolinone derivative 5 at the anomeric carbon $\left(C_{1}\right)$ of $\beta$-D-glucose pentaacetate, followed by ring opening and then ring closure with expulsion of acetate as a leaving group.

The chemical structure of compound 7 was explained by the IR spectrum, whereas it showed a band at $1746 \mathrm{~cm}^{-1}$ compatible with $v_{\mathrm{C}=\mathrm{O}}$ of the acetate groups and lacked the absorption band for the $\mathrm{NH}$ group. Moreover, this structure was also interpreted by the ${ }^{1} \mathrm{H}-\mathrm{NMR}$ spectrum which revealed seven signals at $5.92-3.51 \mathrm{ppm}$ and four singlet signals at 1.97-1.91 ppm all of them corresponding to the protons of $\beta$-D-glucopyranosyl-2,3,4,6-tetraacetate moiety.

Curing of the benzoxazinone derivative 4 with ethanolamine under reflux for $3 \mathrm{~h}$ afforded 3-(2-hydroxyethyl)-2-pentylquinazolin-4(3H)-one 8 as the sole product. The IR spectrum of compound 8 showed a broad band at $3395 \mathrm{~cm}^{-1}$ corresponding to $\mathrm{OH}$ functionality. Furthermore, the ${ }^{1} \mathrm{H}-\mathrm{NMR}$ spectrum appreciably emerged a triplet peak at $4.95 \mathrm{ppm}$ exchangeable with $\mathrm{D}_{2} \mathrm{O}$ corresponding to $\mathrm{OH}$ proton, triplet, and quartet peaks at 4.11 and $3.65 \mathrm{ppm}$, respectively, compatible with ethyl protons of 2-hydroxyethyl moiety. As well, the ${ }^{13} \mathrm{C}-\mathrm{NMR}$ spectrum exhibited two peaks at 58.8 and $46.1 \mathrm{ppm}$ corresponding to the two carbons of 2-hydroxyethyl moiety.

3-Amino-2-pentylquinazolin-4(3H)-one 9 was commenced by refluxing of compound 4 with hydrazine monohydrate in absolute ethanol for $4 \mathrm{~h}$ (Scheme 2). The formation of compound 9 was confirmed by spectroscopic and elemental data. In particular, the ${ }^{1} \mathrm{H}-\mathrm{NMR}$ spectrum of compound 9 manifested a singlet signal commutable in $\mathrm{D}_{2} \mathrm{O}$ at 5.70 ppm corresponding to $\mathrm{NH}_{2}$ protons.

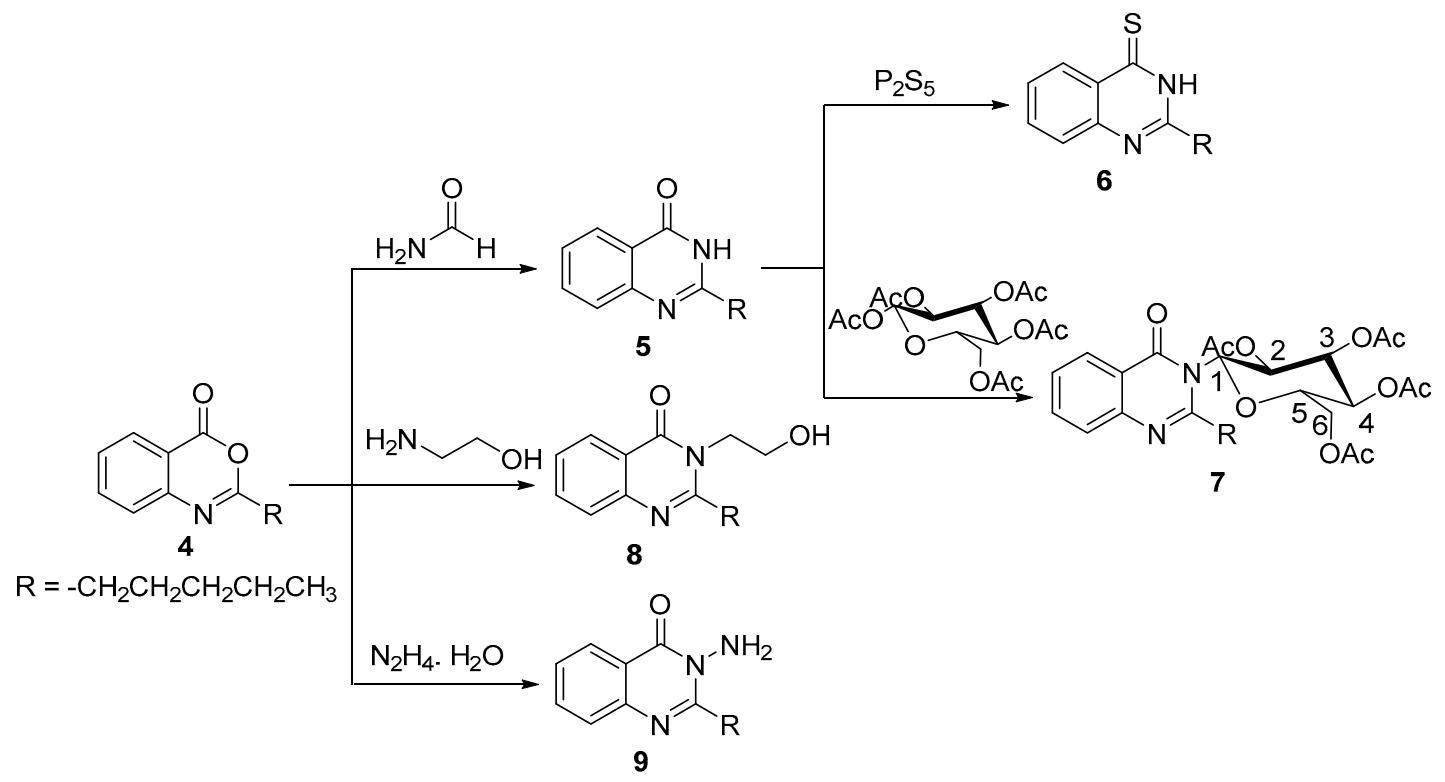

Scheme 2. Synthetic route to compounds 5-9. 
Reaction of 3-amino-2-pentylquinazolin-4(3H)-one 9 with various aldehydes 10a-d gave Schiff bases 11a-d as the sole product in each case (Scheme 3 ). The ${ }^{1} \mathrm{H}-\mathrm{NMR}$ spectra of compounds 11a-d exhibited the appearance of a singlet signal in the region between 8.81-8.69 ppm compatible with methine proton of $\mathrm{N}=\mathrm{CH}$ group.

The thiazolidin-4-one moiety 12 was constructed by the reaction of Schiff base 11a with methyl thioglycolate in absolute ethanol including a small amount of piperidine as a catalyst for $3 \mathrm{~h}$ (Scheme 3). The prospective structure $\mathbf{1 2}$ is in keeping with its spectral and elemental analyses.

Additionally, the nucleophilicity of the amino group of compound 9 was also estimated by fusion of it with 4,5,6,7-tetrachloroisobenzofuran-1,3-dione in oil bath for an hour and that afforded phthalimido derivative 13 in an excellent yield (Scheme 3). The foreseeable structure of compound $\mathbf{1 3}$ was elucidated by their spectral data and elemental analysis. Obviously, its IR spectrum showed stretching absorption bands at 1788 , and $1746 \mathrm{~cm}^{-1}$ corresponding to the carbonyl groups of phthalimido moiety and at 1707 $\mathrm{cm}^{-1}$ corresponding to carbonyl group of the quinazolinone moiety. The ${ }^{1} \mathrm{H}-\mathrm{NMR}$ spectrum exhibited four peaks for four aromatic protons and another four peaks for n-pentyl protons. Furthermore, its ${ }^{13} \mathrm{C}-\mathrm{NMR}$ spectrum emerged variant peaks, all of them fit with the proposed structure.

Eventually, the thione derivative $\mathbf{1 4}$ was obtained via sulfuration of compound 9 by utilizing phosphorus pentasulfide as the above pervious method (Scheme 3). The structure of $\mathbf{1 4}$ was unequivocally explained via the existence of a peak in the ${ }^{13} \mathrm{C}$ NMR spectrum at $182.1 \mathrm{ppm}$ compatible with the carbon of the thione functional group.

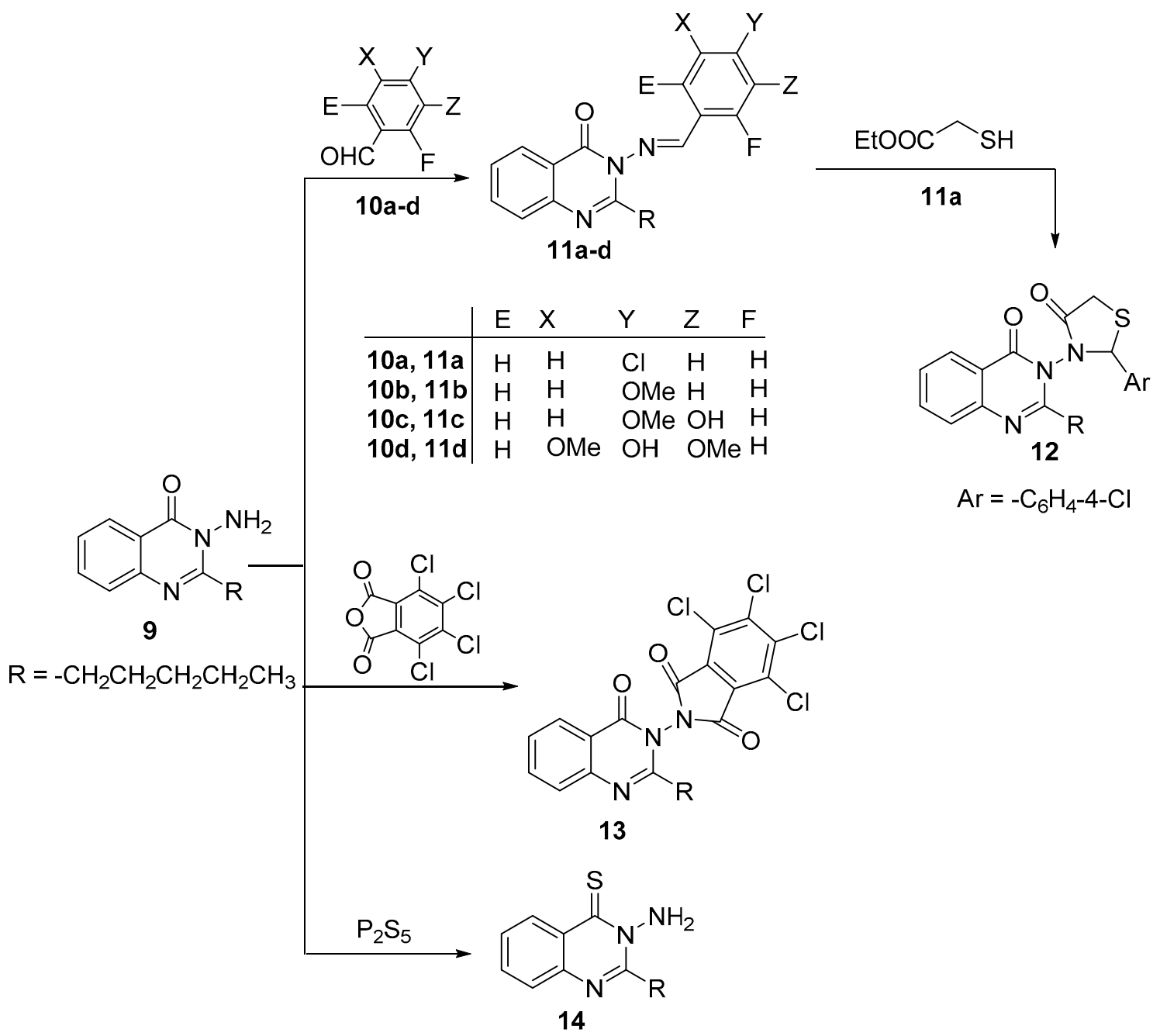

Scheme 3. Synthetic route to compounds 11-14. 


\subsection{Biological Evaluation}

\subsubsection{Antiproliferative Screening}

Twelve compounds possessing quinazolinone(thione) moieties 5-14 along with compound $\mathbf{3}$ were screened against two cell lines, namely hepatocellular carcinoma (HepG2) and mammary gland (MCF-7) in vitro by utilizing MTT assay [42,43]. The latter assay is a colorimetric test based on the change of the yellow MTT (3-(4,5-dimethylthiazolyl-2)-2,5-diphenyltetrazolium bromide) to a purple formazan derivative by mitochondrial succinate dehydrogenase in viable cells and the Doxorubicin (DOX) was used as a standard reference.

The results listed in Table 1 and illustrated in Figure 3, demonstrate that compounds 6 and 11d have a very strong efficacy against $\mathrm{HePG} 2$ cell line with $\mathrm{IC}_{50}$ values at $5.20 \pm 0.5$ and $7.63 \pm 0.6 \mu \mathrm{M}$, respectively. Meanwhile, compounds $\mathbf{6 , 1 1 d}$, and $\mathbf{1 4}$ have a very strong efficacy against the MCF-7 cell line with $\mathrm{IC}_{50}$ values at $6.88 \pm 0.4,8.60 \pm 0.7$, and $10.78 \pm 0.9 \mu \mathrm{M}$, respectively. Compounds $11 \mathbf{b}, 11 \mathrm{c}$ have a strong efficacy against both cell lines with $\mathrm{IC}_{50}$ values in the range $(12.54 \pm 1.1-19.68 \pm 1.6 \mu \mathrm{M})$. For the HePG2 cell line, compounds 5, 9, 11a, and 14 have a moderate efficacy with $\mathrm{IC}_{50}$ values in the range (23.75 $\pm 1.9-41.92 \pm 2.8 \mu \mathrm{M})$. Where, for the MCF-7 cell line, compounds 3, 5, 9, and 11a have a moderate efficacy with $\mathrm{IC}_{50}$ in the range $(21.98 \pm 1.8-47.53 \pm 2.9 \mu \mathrm{M})$. Ultimately, the remaining compounds in both cases have weak efficacies with $\mathrm{IC}_{50}$ values $>50 \mu \mathrm{M}$.

Table 1. Cytotoxic efficacy of thirteen compounds against hepatocellular carcinoma (HePG2) and mammary gland (MCF-7) cell lines.

\begin{tabular}{ccc}
\hline \multirow{2}{*}{ Compounds } & \multicolumn{2}{c}{ In Vitro Cytotoxicity $\mathbf{I C}_{\mathbf{5 0}}(\boldsymbol{\mu M})$} \\
\cline { 2 - 3 } & HePG2 & MCF-7 \\
\hline DOX & $4.50 \pm 0.3$ & $4.17 \pm 0.2$ \\
3 & $52.01 \pm 3.3$ & $47.53 \pm 2.9$ \\
5 & $23.75 \pm 1.9$ & $21.98 \pm 1.8$ \\
6 & $5.20 \pm 0.5$ & $6.88 \pm 0.4$ \\
7 & $66.84 \pm 4.0$ & $54.23 \pm 3.2$ \\
8 & $85.55 \pm 4.5$ & $70.86 \pm 4.1$ \\
9 & $33.27 \pm 2.5$ & $28.69 \pm 2.2$ \\
$11 \mathrm{a}$ & $41.92 \pm 2.8$ & $33.39 \pm 2.5$ \\
$11 \mathrm{~b}$ & $17.27 \pm 1.4$ & $19.68 \pm 1.6$ \\
$11 \mathrm{c}$ & $12.54 \pm 1.1$ & $14.10 \pm 1.3$ \\
$11 \mathrm{~d}$ & $7.63 \pm 0.6$ & $8.60 \pm 0.7$ \\
12 & $76.14 \pm 4.3$ & $59.15 \pm 3.8$ \\
13 & $60.34 \pm 3.8$ & $56.28 \pm 3.5$ \\
14 & $27.39 \pm 2.3$ & $10.78 \pm 0.9$ \\
\hline
\end{tabular}




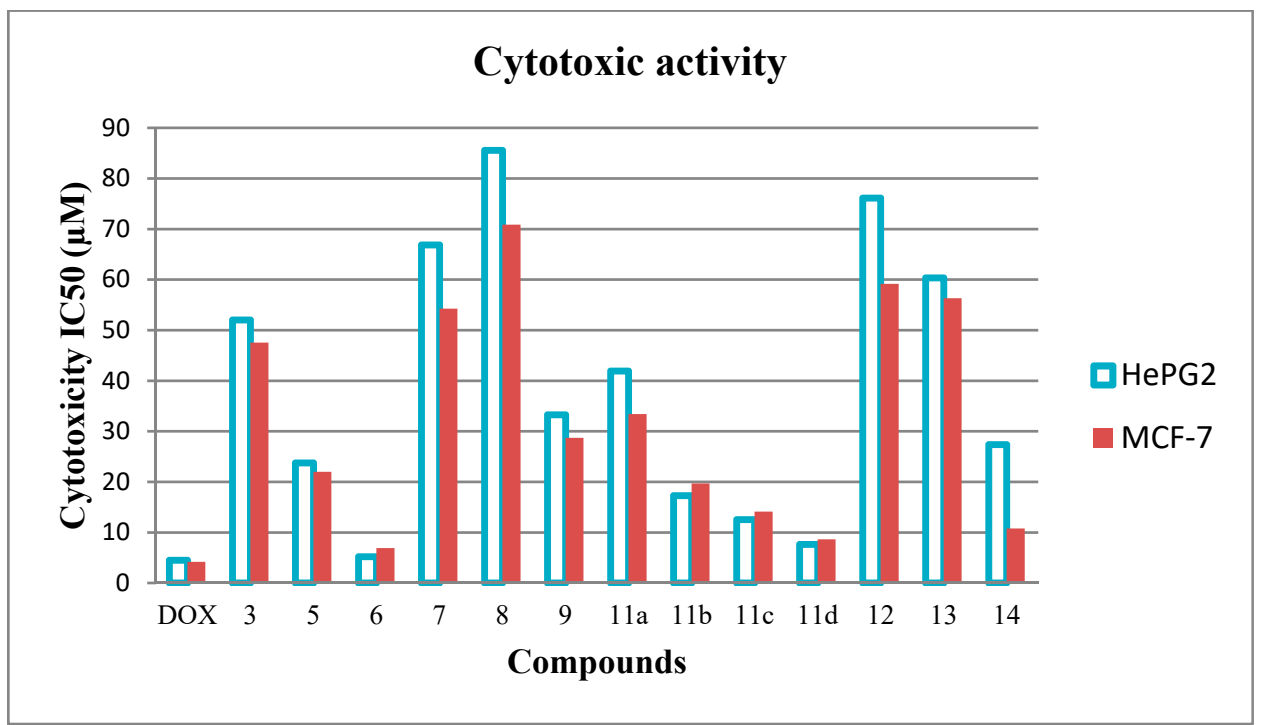

Figure 3. Cytotoxic efficacy of thirteen compounds against HePG2 and MCF-7 cell lines.

Through our screening of the antiproliferative efficacy of the synthesized compounds, it was determined that the average of relative viability of cells (\%) with different concentrations such as 100, 50, $25,12.5,6.25,3.125$, and $1.56 \mu \mathrm{M}$ against two cell lines (HePG2 and MCF-7) as shown in Figures 4 and 5.

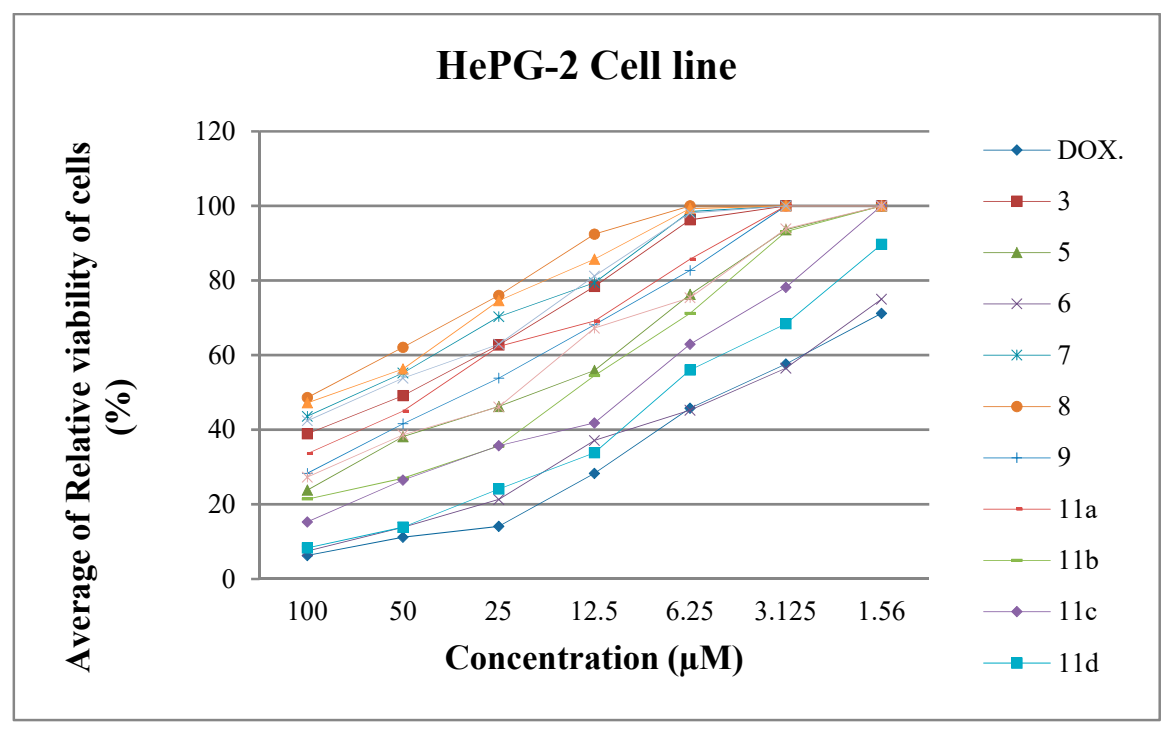

Figure 4. Average of relative viability of HePG-2 cell line (\%) with different concentrations. 


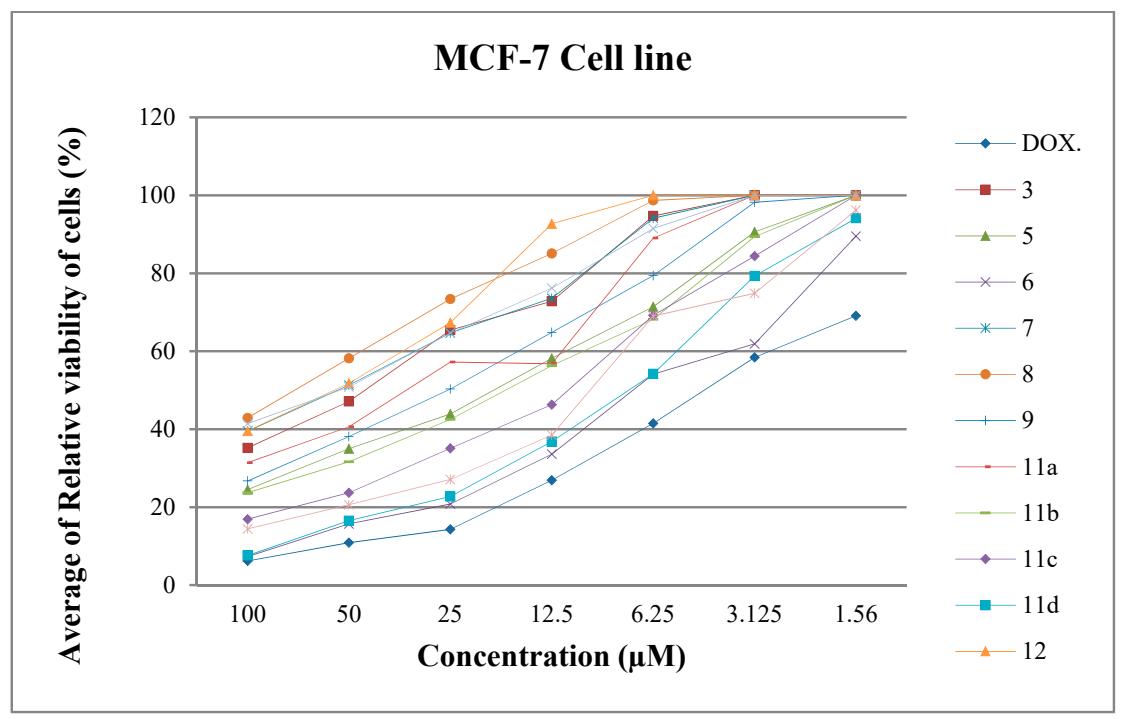

Figure 5. Average of relative viability of MCF-7 cell line (\%) with different concentrations.

Structure Activity Relationship (SAR)

By comparing the antiproliferative efficacy of the thirteen synthesized compounds in this study to their chemical structures, it was concluded that the following structure activity relationship's (SAR's) is hypothesized:

1. Conversion of quinazolin-4(3H)-one derivative 5 to quinazolin-4(3H)-thione derivative 6 enhanced the antiproliferative activity against both cell lines from moderate activity to very strong activity.

2. Similarly, conversion of 3-amino-2-pentylquinazolin-4(3H)-one 9 to 3-amino2-pentylquinazoline-4(3H)-thione $\mathbf{1 4}$ enhanced the antiproliferative activity against both cell lines.

3. Reaction of $\mathbf{9}$ with various aryl aldehydes afforded hydrazone derivatives (11a-d) analoges with variable potencies according to the following sequence: 3,5-(OMe $)_{2}-4-\mathrm{OH}-\mathrm{C}_{6} \mathrm{H}_{2}$ 11d > 3-OH-4-(OMe)- $\mathrm{C}_{6} \mathrm{H}_{3} 11 \mathrm{c}>4-(\mathrm{OMe})-\mathrm{C}_{6} \mathrm{H}_{4} 11 \mathbf{b}>4-\mathrm{Cl}-\mathrm{C}_{6} \mathrm{H}_{4}$ 11a, whereas, the $\mathrm{OH}$ group in $p$-position is more electron donating group than the $\mathrm{OMe}$ group and $\mathrm{Cl}$ atom (i.e., the delocalization of $\mathrm{n}-\pi$ electrons decreased in the above sequence).

4. Construction of the thiazolidinone ring in compound $\mathbf{1 2}$ decreased the antiproliferative activity comparable with the hydrazone derivative 11a, due to decreasing of the delocalization of $n-\pi$ electrons after replacement of the $\mathrm{C}=\mathrm{N}$ group (electron attracting group) by the thiazolidinone ring.

\subsubsection{Antioxidant Activity Screening}

One of the aims of this work is the screening of all synthesized compounds for antioxidant activity using two different methods, namely ABTS [2,2'-azino-bis(3-ethyl benzothiazoline-6-sulfonic acid)] and DPPH assays. DPPH (2,2-diphenyl-1-picryl-hydrazyl-hydrate) free radical assay based on electron-transfer that produces a violet solution in ethanol. This free radical is stable at ambient temperature and reduced in the presence of an antioxidant molecule, leading to colorless ethanol solution. After investigation of these results as listed in Table 2 and Figure 6, it was realized that, compounds 6 and 11d have promising activity through using ABTS assay. Meanwhile, in the case of using DPPH assay, compounds 6, 11d and $\mathbf{1 4}$ have also very high activity. Ascorbic acid was used as a reference through the antioxidant activity screening.

The results depicted in Table 2 and Figure 6 demonstrated that, DPPH assay findings are very approximately related to those of ABTS assay with only one exception, compound $\mathbf{1 4}$ has an excellent antioxidant activity against $\mathrm{DPPH}\left(\mathrm{IC}_{50}=26.87 \pm 0.23 \mu \mathrm{M}\right)$ than that of the ABTS method $\left(\mathrm{IC}_{50}=71.42\right.$ $\pm 0.52 \mu \mathrm{M})$. Noteworthy, all the screened compounds in the case of the DPPH method exhibited $\mathrm{IC}_{50}$ 
smaller than the corresponding ones of the same compounds in the case of the ABTS method, and it proposed that these compounds are more promising scavengers of the DPPH radical than those of the ABTS radical.

By comparing the antioxidant efficacy of the thirteen synthesized compounds in this study to their chemical structures, it was concluded that the following structure antioxidant activity relationship's (SAR's) is hypothesized:

1. The presence of $\mathrm{C}=\mathrm{S}$ enhanced antioxidant activity than the presence of $\mathrm{C}=\mathrm{O}$, as shown in compounds $\mathbf{6}$ and $\mathbf{1 4}$ comparable with compounds $\mathbf{5}$ and $\mathbf{9}$, respectively.

2. The hydrazone derivatives (11a-d) analogs have variable potencies according to the following sequence: 3,5-(OMe $)_{2}-4-\mathrm{OH}-\mathrm{C}_{6} \mathrm{H}_{2}$ 11d $>3-\mathrm{OH}-4-(\mathrm{OMe})-\mathrm{C}_{6} \mathrm{H}_{3} 11 \mathrm{c}>4-(\mathrm{OMe})-\mathrm{C}_{6} \mathrm{H}_{4} 11 \mathbf{b}>4-\mathrm{Cl}-\mathrm{C}_{6} \mathrm{H}_{4}$ 11a, whereas, $\mathrm{OH}$ group in $p$-position is a more electron donating group (has more conjugated system) than $\mathrm{OMe}$ group and $\mathrm{Cl}$ atom.

3. In compound 12 , replacement of $\mathrm{C}=\mathrm{N}$ group by the thiazolidinone ring decreased the antioxidant activity comparable with 11a, because of the lack of the conjugated system.

Table 2. Antioxidant activities of all synthesized compounds by using 2,2'-azino-bis(3-ethyl benzothiazoline-6-sulfonic acid (ABTS) and 2,2-diphenyl-1-picryl-hydrazyl-hydrate (DPPH) methods.

\begin{tabular}{|c|c|c|}
\hline Compounds & ABTS IC $50(\mu \mathrm{M})$ & DPPH IC $50(\mu \mathrm{M})$ \\
\hline Ascorbic acid & $31.26 \pm 0.20$ & $16.83 \pm 0.15$ \\
\hline 3 & $93.24 \pm 0.70$ & $52.14 \pm 0.65$ \\
\hline 5 & $65.13 \pm 0.46$ & $41.16 \pm 0.42$ \\
\hline 6 & $35.48 \pm 0.23$ & $19.25 \pm 0.18$ \\
\hline 7 & $114.63 \pm 0.73$ & $59.43 \pm 0.68$ \\
\hline 8 & $160.92 \pm 0.94$ & $92.36 \pm 0.76$ \\
\hline 9 & $77.38 \pm 0.56$ & $46.23 \pm 0.48$ \\
\hline $11 \mathrm{a}$ & $89.10 \pm 0.64$ & $50.12 \pm 0.54$ \\
\hline $11 b$ & $58.03 \pm 0.41$ & $38.47 \pm 0.37$ \\
\hline $11 \mathrm{c}$ & $52.87 \pm 0.36$ & $32.69 \pm 0.29$ \\
\hline $11 d$ & $46.25 \pm 0.28$ & $22.91 \pm 0.21$ \\
\hline 12 & $154.51 \pm 0.85$ & $73.03 \pm 0.72$ \\
\hline 13 & $131.95 \pm 0.77$ & $65.58 \pm 0.66$ \\
\hline 14 & $71.42 \pm 0.52$ & $26.87 \pm 0.23$ \\
\hline
\end{tabular}

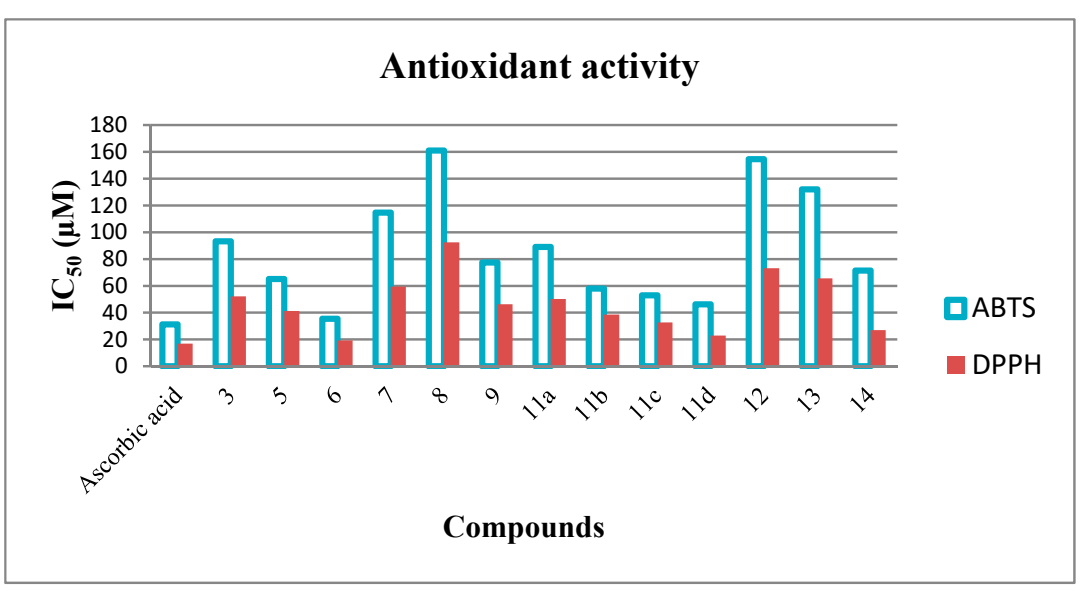

Figure 6. Antioxidant activities of all synthesized compounds by using ABTS and DPPH methods. 
Previous reports of structurally similar compounds (in quinazoline ring) but with different substituents have demonstrated different results in antiproliferative and antioxidant activities from our results $[9,33,44]$.

\subsection{Density Functional Theory}

According to the frontier molecular orbital (FMO) theory, the highest occupied molecular orbital (HOMO) acts as an electron-donor and the lowest unoccupied molecular orbital (LUMO) acts as an electron-acceptor [45]. Meanwhile, both play remarkable roles in the electronic studies by using quantum chemical calculations and they are also of significant importance in modern biochemistry and molecular biology [46]. A molecule is considered as a softer and has an excellent chemical reactivity when it has a smaller energy gap. Meanwhile, a molecule is considered to have a higher chemical hardness and assumed to have good stability when it has a larger energy gap [47-51].

The quantum chemical calculations were implemented by the density functional theory (DFT) method by using the Gaussian(R) 09 program at the B3LYP level in conjunction with 6-31G(d,p) basis set and computed parameters are summarized in Table 3.

By computing and using the energy gap $\left(\Delta E=E_{\mathrm{LUMO}}-E_{\mathrm{HOMO}}\right)$ and dipole moment values beside another quantum chemical parameters such as ionization energy $\left(I=-E_{\mathrm{HOMO}}\right)$, electron affinity $\left(A=-E_{\mathrm{LUMO}}\right)$ [52], chemical hardness $(\eta=(\mathrm{I}-\mathrm{A}) / 2)$, chemical softness $(\mathrm{S}=1 / \eta)$ [53], and binding energy, we can rationally explicate the relation between the chemical structure and the antiproliferative activity (SAR's). Whereas, the energy gap of compound $6(\Delta E=3.98 \mathrm{eV})$ is smaller than that corresponding of compound $5(\Delta E=4.85 \mathrm{eV})$ and also compound 6 has a higher chemical softness value $\left(S=0.50 \mathrm{eV}^{-1}\right)$ than that corresponding of compound $5\left(S=0.41 \mathrm{eV}^{-1}\right)$. These results are matching with the results of the antiproliferative screening whereas, compound $\mathbf{6}$ has a higher potency comparable with compound 5 for both cell lines (HepG2 and MCF-7) as shown in Table 1 and Figure 3. Similarly, compound 14 has a smaller energy gap and a higher chemical softness than that corresponding to compound $\mathbf{9}$ as listed in Table 2. In addition, in vitro compound 14 showed a remarkable higher efficacy comparable with compound 9 as shown in Table 1 and Figure 3. Notably, the dipole moment values of compounds $6(\mu=3.4641 \mathrm{D})$ and $14(\mu=1.852 \mathrm{D})$ are higher than that of compounds $5(\mu=3.2867 \mathrm{D})$ and 9 $(\mu=1.764 \mathrm{D})$, respectively.

On the other hand, compounds 11a-d possess antiproliferative activity in the following order 11d $>$ 11c $>$ 11b $>$ 11a, meanwhile, the energy gaps of these compounds increase in the following order 11a $(\Delta E=2.99 \mathrm{eV})<\mathbf{1 1 d}(\Delta E=3.05 \mathrm{eV})<\mathbf{1 1} \mathrm{c}(\Delta E=3.10 \mathrm{eV})<\mathbf{1 1 b}(\Delta E=3.13 \mathrm{eV})$. The lower of the antiproliferative activity of compound 11a may be explained by values of the dipole moment whereas; the dipole moment of compound 11a is smaller than that of compounds $\mathbf{1 1 b} \mathbf{b} \mathbf{d}$ as shown in Table 3.

Table 3. Quantum chemical parameters of the selected compounds with Density Functional Theory (DFT) at B3LYP/6-31G $(\mathrm{d}, \mathrm{p})$ basis set.

\begin{tabular}{ccccccccc}
\hline Comp. No. & \multirow{2}{*}{$\mathbf{5}$} & $\mathbf{6}$ & $\mathbf{9}$ & $\mathbf{1 4}$ & $\mathbf{1 1 a}$ & $\mathbf{1 1 b}$ & \multirow{2}{*}{ 11c } & 11d \\
\hline E HOMO $(\mathrm{eV})$ & -5.9432 & -5.6352 & -5.9405 & -4.7724 & -5.7277 & -5.6363 & -5.6717 & -5.6602 \\
E LUMO $(\mathrm{eV})$ & -1.0917 & -1.6515 & -1.1298 & -1.6836 & -2.7301 & -2.4983 & -2.5709 & -2.6009 \\
$(\Delta E)$ Energy gap $(\mathrm{eV})$ & 4.8515 & 3.9837 & 4.8107 & 3.0888 & 2.9976 & 3.1380 & 3.1008 & 3.0593 \\
$(I)$ Ionization energy $(\mathrm{eV})$ & 5.9432 & 5.6352 & 5.9405 & 4.7724 & 5.7277 & 5.6363 & 5.6717 & 5.6602 \\
$(\mathrm{~A})$ Electron affinity $(\mathrm{eV})$ & 1.0917 & 1.6515 & 1.1298 & 1.6836 & 2.7301 & 2.4983 & 2.5709 & 2.6009 \\
$(\eta)$ Chemical hardness $(\mathrm{eV})$ & 2.4258 & 1.9919 & 2.4054 & 1.5444 & 1.49881 & 1.56901 & 1.5504 & 1.52969 \\
$(S)$ Chemical softness $(\mathrm{eV}-1)$ & 0.4122 & 0.5020 & 0.4157 & 0.6475 & 0.6672 & 0.6374 & 0.6450 & 0.6537 \\
$\left(E_{\mathrm{T}}\right)$ Binding energy $(\mathrm{a} . \mathrm{u})$ & -689.79 & -1012.73 & -745.11 & -1068.05 & -1473.81 & -1128.73 & -1203.94 & -1318.44 \\
$(\mu)$ Dipole moment $(\mathrm{D})$ & 3.2867 & 3.4641 & 1.764 & 1.852 & 3.2722 & 4.4472 & 4.1944 & 6.232 \\
\hline
\end{tabular}

The distributions of the HOMO and LUMO orbitals of the selected compounds are computed at the same level of the DFT theory and are provided in Figures 7 and 8. The results manifested that possible reactive sites exist as shown below: 
1. The HOMO of compounds $\mathbf{5}$ and $\mathbf{9}$ are nearly similar and the distribution of orbitals are mainly situated on the quinazolinone moiety, also, the LUMO of these compounds are situated on the same moiety.

2. The HOMO of compounds $\mathbf{6}$ and $\mathbf{1 4}$ are nearly similar and the distribution of orbitals are mainly situated on $\mathrm{C}=\mathrm{S}$, while, the LUMO of these compounds are mainly situated on the quinazolinthione moiety.

3. The HOMO of compounds 11a- $\mathbf{d}$ are nearly similar and the distribution of orbitals are mainly situated on the quniazolinone moiety, meanwhile, the LUMO of these compounds are mainly situated on the aryl aldehyde hydrazone system.

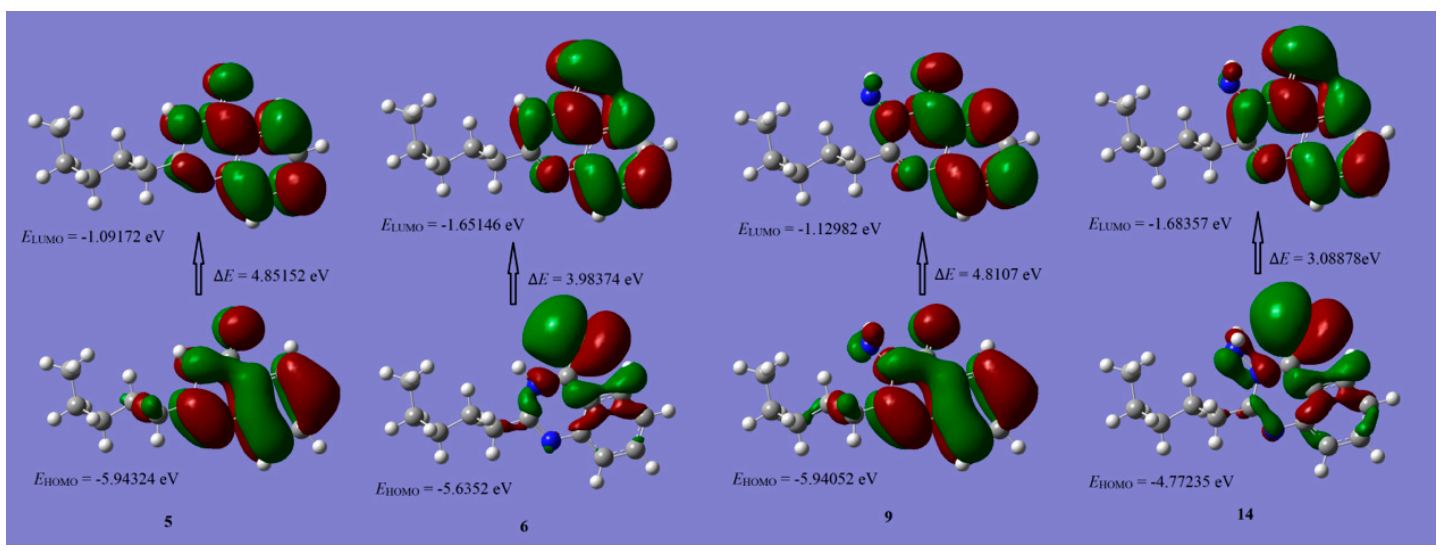

Figure 7. Schematic representation of HOMO and LUMO coefficient distribution of compounds 5, 6, 9, and 14.

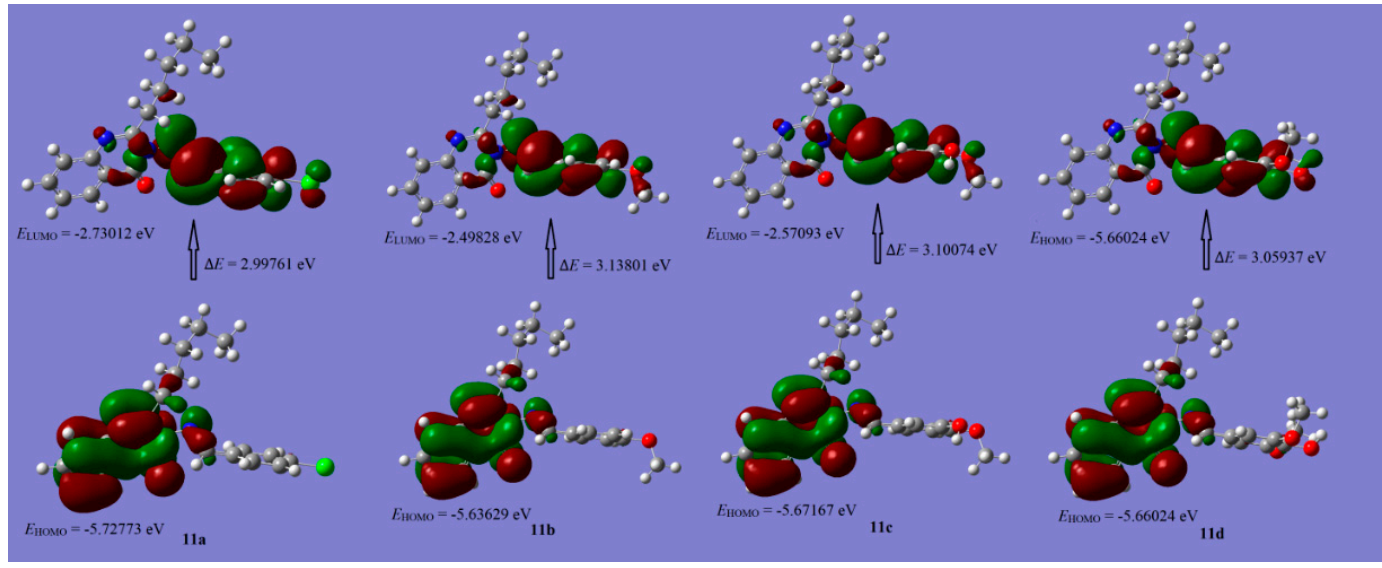

Figure 8. Schematic representation of highest occupied molecular orbital (HOMO) and loest unoccupied molecular orbital (LUMO) coefficient distribution of compounds 11a-d.

\section{Materials and Methods}

\subsection{Chemistry}

The melting point is uncorrected and was measured on a Stuart SMP 30 advanced digital electric melting point apparatus (Cole-Parmer, Staffordshire, UK). All reactions were monitored by TLC (Kieselgel $60 \mathrm{~F}_{254}$, Merck, Munchen, Germany) and spots were visualized using UV (254 nm), In the region (400-4000 $\mathrm{cm}^{-1}$ ), the IR spectrum was measured in the $\mathrm{KBr}$ phase by using the Nicolet iS10 FT-IR spectrometer (Shimadzu Corporation, Kyoto, Japan). The ${ }^{1} \mathrm{H}-\mathrm{NMR}$ (at $400 \mathrm{MHz}$ ) and ${ }^{13} \mathrm{C}-\mathrm{NMR}$ (at $100 \mathrm{MHz}$ ) spectra were performed at chemical warfare labs, Egypt, with a Varian Gemini spectrometer (Metrohim, California, United States) in DMSO- $d_{6}$ as a solvent by using tetramethylsilane (TMS) as a reference. Perkin-Elmer 2400 CHN elemental analyzer (Waltham, MA, USA) was used to 
record CHN elemental analysis at the Faculty of Science, Cairo University, Egypt. The mass spectrum was measured on Shimadzu GC-MS QP1000EX apparatus (Shimadzu Corporation, Kyoto, Japan) at the central analytical lab, Ain Shams University, Cairo, Egypt.

\subsubsection{2-Hexanamidobenzoic Acid 3}

Hexanoyl chloride $\mathbf{2}(1.39 \mathrm{~mL}, 0.01 \mathrm{~mol})$ was added dropwise to anthranilic acid $\mathbf{1}(1.37 \mathrm{~g}, 0.01 \mathrm{~mol})$ dissolved in dry pyridine $(20 \mathrm{~mL})$ at ambient temperature with stirring. The stirring was continued for an hour, and then the resulting emulsion was acidified with cold $10 \% \mathrm{HCl}$ solution. The white solid which separated was collected by filtration and then recrystallized from benzene to give 3 [38] as white crystals; m.p.: $92-95^{\circ} \mathrm{C}$ (Lit. m.p.: $93-95^{\circ} \mathrm{C}$ ) [38], yield: 92\%. IR $\left(\mathrm{KBr}, \mathrm{cm}^{-1}\right)$ : 3426-2463 (br) $(\mathrm{OH}), 3206(\mathrm{NH}), 2959,2934,2861\left(\mathrm{CH}_{\text {aliph. }}\right), 1691,1637$ (C=O). ${ }^{1} \mathrm{H}-\mathrm{NMR}\left(400 \mathrm{MHz}, \mathrm{DMSO}-d_{6}\right) \delta(\mathrm{ppm})$ : 13.51 (br.s, $1 \mathrm{H}, \mathrm{OH}$, exchangeable with $\left.\mathrm{D}_{2} \mathrm{O}\right), 11.09\left(\mathrm{~s}, 1 \mathrm{H}, \mathrm{NH}\right.$, exchangeable with $\left.\mathrm{D}_{2} \mathrm{O}\right), 8.48(\mathrm{~d}, 1 \mathrm{H}$, $\left.\operatorname{Ar}-\mathrm{H}, \mathrm{H}_{\mathrm{a}}, J=8.8 \mathrm{~Hz}\right), 7.95\left(\mathrm{~d}, 1 \mathrm{H}, \mathrm{Ar}-\mathrm{H}, \mathrm{H}_{\mathrm{d}}, J=8.0 \mathrm{~Hz}\right), 7.55\left(\mathrm{t}, 1 \mathrm{H}, \mathrm{Ar}-\mathrm{H}, \mathrm{H}_{\mathrm{c}}, J=7.8 \mathrm{~Hz}, J=8.0 \mathrm{~Hz}\right)$, $7.11\left(\mathrm{t}, 1 \mathrm{H}, \mathrm{Ar}-\mathrm{H}, \mathrm{H}_{\mathrm{b}}, J=7.4 \mathrm{~Hz}, J=7.8 \mathrm{~Hz}\right), 2.35\left(\mathrm{t}, 2 \mathrm{H}, \mathrm{COCH}_{2}, J=7.2 \mathrm{~Hz}, J=7.6 \mathrm{~Hz}\right), 1.60$ (quintet, $\left.2 \mathrm{H}, \mathrm{COCH}_{2} \mathrm{CH}_{2}, J=7.2 \mathrm{~Hz}, J=7.6 \mathrm{~Hz}\right), 1.31-1.26\left(\mathrm{~m}, 4 \mathrm{H}, \mathrm{CH}_{3} \mathrm{CH}_{2} \mathrm{CH}_{2}\right), 0.85\left(\mathrm{t}, 3 \mathrm{H}, \mathrm{CH}_{3}, J=6.8 \mathrm{~Hz}\right.$,

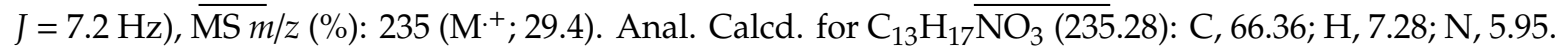
Found: C, 66.36; H, 7.28; N, 5.95.

\subsubsection{2-Pentyl-4H-benzo[d][1,3]oxazin-4-one 4}

A suspension of 2-hexanamidobenzoic acid $3(2.35 \mathrm{~g}, 0.01 \mathrm{~mol})$ in freshly distilled acetic anhydride $(10 \mathrm{~mL})$ was heated in water bath for an hour followed by a concentration of the mixture in vacuo and used in situ $[39,40]$.

\subsubsection{2-Pentylquinazolin-4(3H)-one 5}

A solution of benzoxazinone $4(2.17 \mathrm{~g}, 0.01 \mathrm{~mol})$ in formamide $(15 \mathrm{~mL})$ was refluxed for $7 \mathrm{~h}$. After cooling, the reaction mixture was poured onto ice cold water, the obtained solid was filtered off, dried, and recrystallized from petroleum ether $60-80{ }^{\circ} \mathrm{C}$ to give 5 [41] as white crystals; m.p.: $142-144{ }^{\circ} \mathrm{C}$ (Lit. m.p.: 153-154 $\left.{ }^{\circ} \mathrm{C}\right)$ [41], yield: $92 \%$. IR $\left(\mathrm{KBr} \mathrm{cm}^{-1}\right): 3171(\mathrm{NH}), 2958,2928,2860\left(\mathrm{CH}_{\text {aliph. }}\right), 1680$ $(\mathrm{C}=\mathrm{O}), 1614(\mathrm{C}=\mathrm{N}$ or $\mathrm{C}=\mathrm{C}) .{ }^{1} \mathrm{H}-\mathrm{NMR}\left(400 \mathrm{MHz}, \mathrm{DMSO}-d_{6}\right) \delta(\mathrm{ppm}): 12.13(\mathrm{~s}, 1 \mathrm{H}, \mathrm{NH}$, exchangeable with $\left.\mathrm{D}_{2} \mathrm{O}\right), 8.05\left(\mathrm{~d}, 1 \mathrm{H}, \mathrm{Ar}-\mathrm{H}, \mathrm{H}_{\mathrm{a}}, J=8.0 \mathrm{~Hz}\right), 7.74\left(\mathrm{t}, 1 \mathrm{H}, \mathrm{Ar}-\mathrm{H}, \mathrm{H}_{\mathrm{c}}, J=7.6 \mathrm{~Hz}, J=7.8 \mathrm{~Hz}\right), 7.56(\mathrm{~d}, 1 \mathrm{H}$, $\left.\mathrm{Ar}-\mathrm{H}, \mathrm{H}_{\mathrm{d}}, J=8 \mathrm{~Hz}\right), 7.42\left(\mathrm{t}, 1 \mathrm{H}, \mathrm{Ar}-\mathrm{H}, \mathrm{H}_{\mathrm{b}}, J=7.6 \mathrm{~Hz}\right), 2.56\left(\mathrm{t}, 2 \mathrm{H}, \mathrm{N}=\mathrm{CCH}_{2}, J=7.6 \mathrm{~Hz}, J=8.0 \mathrm{~Hz}\right)$, 1.70 (quintet, $\left.2 \mathrm{H}, \mathrm{N}=\mathrm{CCH}_{2} \mathrm{CH}_{2}, J=7.6 \mathrm{~Hz}, J=7.2 \mathrm{~Hz}\right), 1.30-1.26\left(\mathrm{~m}, 4 \mathrm{H}, \mathrm{CH}_{3} \mathrm{CH}_{2} \mathrm{CH}_{2}\right), 0.84(\mathrm{t}, 3 \mathrm{H}$, $\left.\mathrm{CH}_{3}, J=6.8 \mathrm{~Hz}, J=7.2 \mathrm{~Hz}\right) .{ }^{13} \mathrm{C}-\mathrm{NMR}\left(100 \mathrm{MHz}, \mathrm{DMSO}-d_{6}\right) \delta(\mathrm{ppm}): 162.2,157.9,149.4,134.7,127.2$, 126.3, 126.1, 121.2, 34.9, 31.1, 26.9, 22.2, 14.2. MS m/z (\%): $216\left(\mathrm{M}^{+} ; 26.3\right)$. Anal. Calcd. for $\mathrm{C}_{13} \mathrm{H}_{16} \mathrm{~N}_{2} \mathrm{O}$ (216.28): C, 72.19; H, 7.46; N, 12.95. Found: C, 72.26; H, 7.49; N, 12.86.

\subsubsection{2-Pentylquinazoline-4(3H)-thione 6}

To a solution of quinazolinone $5(2.16 \mathrm{~g}, 0.01 \mathrm{~mol})$ in dry toluene $(30 \mathrm{~mL}), \mathrm{P}_{2} \mathrm{~S}_{5}(2.22 \mathrm{~g}, 0.01 \mathrm{~mol})$ was added. The reaction mixture was refluxed for $1 \mathrm{~h}$, and then filtered off. The obtained filtrate was evaporated under reduced pressure, the formed solid was collected by filtration, dried, and recrystallized from ethanol to give 6 as light brown crystals; m.p.: $101-103{ }^{\circ} \mathrm{C}$, yield: $76 \%$. IR $(\mathrm{KBr}$, $\left.\mathrm{cm}^{-1}\right)$ : 3184, $3141(\mathrm{NH}), 2967,2935,2852\left(\mathrm{CH}_{\text {aliph }}\right), 1618(\mathrm{C}=\mathrm{N}), 1604(\mathrm{C}=\mathrm{C}), 1236(\mathrm{C}=\mathrm{S}) .{ }^{1} \mathrm{H}-\mathrm{NMR}$ $\left(400 \mathrm{MHz}, \mathrm{DMSO}-d_{6}\right) \delta(\mathrm{ppm}): 13.69\left(\mathrm{~s}, 1 \mathrm{H}, \mathrm{NH}\right.$, exchangeable with $\left.\mathrm{D}_{2} \mathrm{O}\right), 8.52\left(\mathrm{~d}, 1 \mathrm{H}, \mathrm{Ar}-\mathrm{H}, \mathrm{H}_{\mathrm{d}}\right.$, $J=8.4 \mathrm{~Hz}), 7.83\left(\mathrm{t}, 1 \mathrm{H}, \mathrm{Ar}-\mathrm{H}, \mathrm{H}_{\mathrm{c}}, J=7.6 \mathrm{~Hz}\right), 7.63\left(\mathrm{~d}, 1 \mathrm{H}, \mathrm{Ar}-\mathrm{H}, \mathrm{H}_{\mathrm{a}}, J=8.4 \mathrm{~Hz}\right), 7.52\left(\mathrm{t}, 1 \mathrm{H}, \mathrm{Ar}-\mathrm{H}, \mathrm{H}_{\mathrm{b}}\right.$ ， $J=7.4 \mathrm{~Hz}, J=7.8 \mathrm{~Hz}), 2.70\left(\mathrm{t}, 2 \mathrm{H}, \mathrm{N}=\mathrm{CCH}_{2}, J=7.6 \mathrm{~Hz}, J=8.0 \mathrm{~Hz}\right.$ ), 1.72 (quintet, $2 \mathrm{H}, \mathrm{N}=\mathrm{CCH}_{2} \mathrm{CH}_{2}$, $J=7.6 \mathrm{~Hz}, J=7.2 \mathrm{~Hz}), 1.31-1.26\left(\mathrm{~m}, 4 \mathrm{H}, \mathrm{CH}_{3} \mathrm{CH}_{2} \mathrm{CH}_{2}\right), 0.85\left(\mathrm{t}, 3 \mathrm{H}, \mathrm{CH}_{3}, J=6.8 \mathrm{~Hz}\right) . \mathrm{MS} \mathrm{m} / z(\%): 232$ $\left(\mathrm{M}^{+}\right.$; 16.7). Anal. Calcd. for $\mathrm{C}_{13} \mathrm{H}_{16} \mathrm{~N}_{2} \mathrm{~S}$ (232.35): $\mathrm{C}, 67.20 ; \mathrm{H}, 6.94 ; \mathrm{N}, 12.06 ; \mathrm{S}, 13.80$. Found: $\mathrm{C}, 67.31$; $\mathrm{H}, 7.03 ; \mathrm{N}, 12.01 ; \mathrm{S}, 13.85$. 


\subsection{5. $N$-( $\beta$-D-Glucopyranosyl-2,3,4,6-tetraacetate)-2-pentylquinazolin-4(3H)-one 7}

Quinazolinone $5(2.16 \mathrm{~g}, 0.01 \mathrm{~mol})$ was refluxed with $\beta$-D-glucose pentaacetate $(3.90 \mathrm{~g}, 0.01 \mathrm{~mol})$ in absolute ethanol $(50 \mathrm{~mL})$ for $3 \mathrm{~h}$. the solid obtained after slow evaporation of the resulting solution was collected and recrystallized from ethanol to give 7 as white crystals; m.p.: $135-137^{\circ} \mathrm{C}$, yield: $62 \%$. IR $\left(\mathrm{KBr}, \mathrm{cm}^{-1}\right):$ 2955, 2924, $2854\left(\mathrm{CH}_{\text {aliph. }}\right), 1746\left(\mathrm{C}=\mathrm{O}_{\text {ester }}\right), 1678\left(\mathrm{C}=\mathrm{O}_{\text {quinazolinone }}\right), 1613(\mathrm{C}=\mathrm{N}) .{ }^{1} \mathrm{H}-\mathrm{NMR}$ $\left(400 \mathrm{MHz}, \mathrm{DMSO}-d_{6}\right) \delta(\mathrm{ppm}): 8.05\left(\mathrm{~d}, 1 \mathrm{H}, \mathrm{Ar}-\mathrm{H}, \mathrm{H}_{\mathrm{a}}, J=8.0 \mathrm{~Hz}\right), 7.74\left(\mathrm{t}, 1 \mathrm{H}, \mathrm{Ar}-\mathrm{H}, \mathrm{H}_{\mathrm{c}}, J=8.4 \mathrm{~Hz}\right.$, $J=6.8 \mathrm{~Hz}), 7.56\left(\mathrm{~d}, 1 \mathrm{H}, \mathrm{Ar}-\mathrm{H}, \mathrm{H}_{\mathrm{d}}, J=8.4 \mathrm{~Hz}\right), 7.43\left(\mathrm{t}, 1 \mathrm{H}, \mathrm{Ar}-\mathrm{H}, \mathrm{H}_{\mathrm{b}}, J=8.0 \mathrm{~Hz}, J=7.2 \mathrm{~Hz}\right), 5.92(\mathrm{~d}$, $\left.1 \mathrm{H}, \mathrm{C}_{1}-\mathrm{H}, J=8.4 \mathrm{~Hz}\right), 5.39\left(\mathrm{t}, 1 \mathrm{H}, \mathrm{C}_{2}-\mathrm{H}, J=9.6 \mathrm{~Hz}\right), 4.93\left(\mathrm{t}, 1 \mathrm{H}, \mathrm{C}_{3}-\mathrm{H}, J=9.6 \mathrm{~Hz}\right), 4.90\left(\mathrm{t}, 1 \mathrm{H}, \mathrm{C}_{4}-\mathrm{H}\right.$, $J=8.4 \mathrm{~Hz}, J=10.0 \mathrm{~Hz}), 4.14,412\left(\mathrm{~d}, \mathrm{~d}, 1 \mathrm{H}, \mathrm{C}_{6}-\mathrm{H}, J=10.4 \mathrm{~Hz}, J=5.6 \mathrm{~Hz}\right), 3.97\left(\mathrm{~d}, 1 \mathrm{H}, \mathrm{C}_{6}-\mathrm{H}, J=10.4 \mathrm{~Hz}\right)$, $3.51\left(\mathrm{~m}, 1 \mathrm{H}, \mathrm{C}_{5}-\mathrm{H}\right), 2.56\left(\mathrm{t}, 2 \mathrm{H}, \mathrm{N}=\mathrm{CCH}_{2}, J=8.0 \mathrm{~Hz}, J=7.6 \mathrm{~Hz}\right), 1.978\left(\mathrm{~s}, 3 \mathrm{H}, \mathrm{CH}_{3}\right), 1.973\left(\mathrm{~s}, 3 \mathrm{H}, \mathrm{CH}_{3}\right)$, $1.961\left(\mathrm{~s}, 3 \mathrm{H}, \mathrm{CH}_{3}\right), 1.917\left(\mathrm{~s}, 3 \mathrm{H}, \mathrm{CH}_{3}\right), 1.69$ (quintet, $\left.2 \mathrm{H}, \mathrm{N}=\mathrm{CCH}_{2} \mathrm{CH}_{2}, J=7.6 \mathrm{~Hz}, J=6.8 \mathrm{~Hz}\right), 1.31-1.26$ $\left(\mathrm{m}, 4 \mathrm{H}, \mathrm{CH}_{3} \mathrm{CH}_{2} \mathrm{CH}_{2}\right), 0.84\left(\mathrm{t}, 3 \mathrm{H}, \mathrm{CH}_{3}, J=6.8 \mathrm{~Hz}, J=7.2 \mathrm{~Hz}\right) . \mathrm{MS} \mathrm{m} / z(\%): 546\left(\mathrm{M}^{+} ; 32.4\right)$. Anal. Calcd. for $\mathrm{C}_{27} \mathrm{H}_{34} \mathrm{~N}_{2} \mathrm{O}_{10}$ (546.57): C, 59.33; $\mathrm{H}, 6.27 ; \mathrm{N}, 5.13$. Found: $\mathrm{C}, 59.18 ; \mathrm{H}, 6.21 ; \mathrm{N}, 5.08$.

\subsubsection{3-(2-Hydroxyethyl)-2-pentylquinazolin-4(3H)-one 8}

A solution of benzoxazinone $4(2.17 \mathrm{~g}, 0.01 \mathrm{~mol})$ in ethanolamine $(15 \mathrm{~mL})$ was heated under reflux for $3 \mathrm{~h}$. The reaction mixture was poured onto ice cold water, the obtained solid was filtered off, dried, and then recrystallized from ethanol to give 8 as white crystals; m.p.: $84-85^{\circ} \mathrm{C}$, yield: $47 \%$. IR $(\mathrm{KBr}$, $\left.\mathrm{cm}^{-1}\right)$ : $3395(\mathrm{OH}), 2953,2931,2872\left(\mathrm{CH}_{\text {aliph. }}\right), 1648(\mathrm{C}=\mathrm{O}), 1611(\mathrm{C}=\mathrm{N}) .{ }^{1} \mathrm{H}-\mathrm{NMR}\left(400 \mathrm{MHz}, \mathrm{DMSO}-d_{6}\right)$ $\delta(\mathrm{ppm}): 8.07\left(\mathrm{~d}, 1 \mathrm{H}, \mathrm{Ar}-\mathrm{H}, \mathrm{H}_{\mathrm{a}}, J=8.0 \mathrm{~Hz}\right), 7.75\left(\mathrm{t}, 1 \mathrm{H}, \mathrm{Ar}-\mathrm{H}, \mathrm{H}_{\mathrm{c}}, J=7.8 \mathrm{~Hz}, J=7.6 \mathrm{~Hz}\right), 7.57(\mathrm{~d}, 1 \mathrm{H}$, $\left.\mathrm{Ar}-\mathrm{H}, \mathrm{H}_{\mathrm{d}}, J=8.0 \mathrm{~Hz}\right), 7.44\left(\mathrm{t}, 1 \mathrm{H}, \mathrm{Ar}-\mathrm{H}, \mathrm{H}_{\mathrm{b}}, J=7.6 \mathrm{~Hz}, J=7.2 \mathrm{~Hz}\right), 4.95(\mathrm{t}, 1 \mathrm{H}, \mathrm{OH}$, exchangeable with $\left.\mathrm{D}_{2} \mathrm{O}, J=5.6 \mathrm{~Hz}\right), 4.11\left(\mathrm{t}, 2 \mathrm{H}, \mathrm{CH}_{2} \mathrm{CH}_{2} \mathrm{OH}, J=5.6 \mathrm{~Hz}, J=6.0 \mathrm{~Hz}\right), 3.65\left(\mathrm{q}, 2 \mathrm{H}, \mathrm{CH}_{2} \mathrm{OH}, J=6.0 \mathrm{~Hz}\right.$, $J=5.6 \mathrm{~Hz}$ ), $2.93\left(\mathrm{t}, 2 \mathrm{H}, \mathrm{N}=\mathrm{CC} \overline{\mathrm{H}_{2}, J}=7.6 \mathrm{~Hz}, J=8.0 \mathrm{~Hz}\right.$ ), 1.75 (quintet, $2 \mathrm{H}, \mathrm{N}=\mathrm{CC}_{\mathrm{CH}_{2}} \mathrm{CH}_{2}, J=7.6 \mathrm{~Hz}$, $J=7.6 \mathrm{~Hz}), 1.40-1.32\left(\mathrm{~m}, 4 \mathrm{H}, \mathrm{CH}_{3} \mathrm{CH}_{2} \mathrm{CH}_{2}\right), 0.88\left(\mathrm{t}, 3 \mathrm{H}, \mathrm{CH}_{3}, J=7.2 \mathrm{~Hz}\right) .{ }^{13} \mathrm{C}-\mathrm{NMR}(100 \mathrm{MHz}$, DMSO- $d_{6}$ ) $\delta$ (ppm): 161.7, 158.4, 147.4, 134.6, 127.1, 126.5, 126.4, 120.4, 58.8, 46.1, 34.6, 31.3, 26.3, 22.4, 14.3. MS $m / z(\%): 260\left(\mathrm{M}^{+} ; 41.2\right)$. Anal. Calcd. for $\mathrm{C}_{15} \mathrm{H}_{20} \mathrm{~N}_{2} \mathrm{O}_{2}$ (260.34): C, 69.20; $\mathrm{H}, 7.74 ; \mathrm{N}, 10.76$. Found: $\mathrm{C}, 69.17 ; \mathrm{H}, 7.68 ; \mathrm{N}, 10.81$.

\subsubsection{3-Amino-2-pentylquinazolin-4(3H)-one 9}

A mixture of benzoxazinone $4(2.17 \mathrm{~g}, 0.01 \mathrm{~mol})$ and hydrazine hydrate $(1.5 \mathrm{~mL})$ in absolute ethanol $(20 \mathrm{~mL})$ was refluxed for $3 \mathrm{~h}$. The mixture was poured onto ice cold water, the formed solid was filtered off, and recrystallized from ethanol to give 9 as buff crystals; m.p.: $58-60{ }^{\circ} \mathrm{C}$, yield: $43 \%$. IR $\left(\mathrm{KBr}, \mathrm{cm}^{-1}\right)$ : 3306, $3263\left(\mathrm{NH}_{2}\right), 2954,2931,2910,2856\left(\mathrm{CH}_{\text {aliph. }}\right), 1673(\mathrm{C}=\mathrm{O}), 1630(\mathrm{C}=\mathrm{N}) .{ }^{1} \mathrm{H}$ NMR $\left(400 \mathrm{MHz}, \mathrm{DMSO}-d_{6}\right) \delta(\mathrm{ppm}): 8.08\left(\mathrm{~d}, 1 \mathrm{H}, \mathrm{Ar}-\mathrm{H}, \mathrm{H}_{\mathrm{a}}, J=7.8 \mathrm{~Hz}\right), 7.75\left(\mathrm{t}, 1 \mathrm{H}, \mathrm{Ar}-\mathrm{H}, \mathrm{H}_{\mathrm{c}}, J=7.4 \mathrm{~Hz}\right.$, $J=7.8 \mathrm{~Hz}), 7.59\left(\mathrm{~d}, 1 \mathrm{H}, \mathrm{Ar}-\mathrm{H}, \mathrm{H}_{\mathrm{d}}, J=7.6 \mathrm{~Hz}\right), 7.45\left(\mathrm{t}, 1 \mathrm{H}, \mathrm{Ar}-\mathrm{H}, \mathrm{H}_{\mathrm{b}}, J=7.2 \mathrm{~Hz}, J=7.6 \mathrm{~Hz}\right), 5.70(\mathrm{~s}$, $2 \mathrm{H}, \mathrm{NH}_{2}$, exchangeable with $\left.\mathrm{D}_{2} \mathrm{O}\right), 2.90\left(\mathrm{t}, 2 \mathrm{H}, \mathrm{N}=\mathrm{CCH}_{2}, J=7.2 \mathrm{~Hz}, J=8.0 \mathrm{~Hz}\right), 1.74$ (quintet, $2 \mathrm{H}$, $\left.\mathrm{N}=\mathrm{CCH}_{2} \mathrm{CH}_{2}, J=7.6 \mathrm{~Hz}, J=7.2 \mathrm{~Hz}\right), 1.37-1.30\left(\mathrm{~m}, 4 \mathrm{H}, \mathrm{CH}_{3} \mathrm{CH}_{2} \mathrm{CH}_{2}\right), 0.87\left(\mathrm{t}, 3 \mathrm{H}, \mathrm{CH}_{3}, J=6.4 \mathrm{~Hz}\right.$, $J=7.2 \mathrm{~Hz}) .{ }^{13} \mathrm{C}-\mathrm{NMR}\left(400 \mathrm{MHz}, \mathrm{DMSO}_{6}\right) \delta(\mathrm{ppm}): 160.9,158.8,147.0,134.3,127.2,126.39,126.31$, 120.2, 34.0, 31.4, 26.0, 22.3, 14.3. MS $m / z$ (\%): $231\left(\mathrm{M}^{+}\right.$; 41.1). Anal. Calcd. for $\mathrm{C}_{13} \mathrm{H}_{17} \mathrm{~N}_{3} \mathrm{O}$ (231.30): $\mathrm{C}$, 67.51; H, 7.41; N, 18.17. Found: C, 67.39; H, 7.34; N, 18.24 .

\subsubsection{General Procedure for Synthesis of 11a-d}

A mixture of compound $9(2.31 \mathrm{~g}, 0.01 \mathrm{~mol})$ and the appropriate aldehydes 10a-d $(0.01 \mathrm{~mol})$ in absolute ethanol $(30 \mathrm{~mL})$ was refluxed for $4-6 \mathrm{~h}$. The reaction mixture was evaporated under reduced pressure; the obtained residue was collected and recrystallized from the proper solvent to give the corresponding benzylidene derivatives 11a-d, respectively. 
3-((4-Chlorobenzylidene)amino)-2-pentylquinazolin-4(3H)-one 11a

Yellow crystals; m.p.: $176-178{ }^{\circ} \mathrm{C}$ (ethanol), yield: $72 \%$. IR $\left(\mathrm{KBr}, \mathrm{cm}^{-1}\right): 2943,2866\left(\mathrm{CH}_{\text {aliph. }}\right), 1667$ $(\mathrm{C}=\mathrm{O}), 1624(\mathrm{C}=\mathrm{N}) .{ }^{1} \mathrm{H}-\mathrm{NMR}\left(400 \mathrm{MHz}, \mathrm{DMSO}-d_{6}\right) \delta(\mathrm{ppm}): 8.69(\mathrm{~s}, 1 \mathrm{H}, \mathrm{N}=\mathrm{CH}), 7.95(\mathrm{~d}, 1 \mathrm{H}, \mathrm{Ar}-\mathrm{H}$, $\left.\mathrm{H}_{\mathrm{a}}, J=7.8 \mathrm{~Hz}\right), 7.88\left(\mathrm{~d}, 2 \mathrm{H}, \mathrm{Ar}-\mathrm{H}, \mathrm{H}_{\mathrm{E}}+\mathrm{H}_{\mathrm{F}}, J=8.8 \mathrm{~Hz}\right), 7.66\left(\mathrm{t}, 1 \mathrm{H}, \mathrm{Ar}-\mathrm{H}, \mathrm{H}_{\mathrm{c}}, J=8.4 \mathrm{~Hz}\right), 7.57(\mathrm{~d}, 3 \mathrm{H}$, Ar-H, $\left.\mathrm{H}_{\mathrm{d}}+\mathrm{H}_{\mathrm{X}}+\mathrm{H}_{\mathrm{Z}}\right), 7.46\left(\mathrm{t}, 1 \mathrm{H}, \mathrm{Ar}-\mathrm{H}, \mathrm{H}_{\mathrm{b}}, J=8.4 \mathrm{~Hz}\right), 2.34\left(\mathrm{t}, 2 \mathrm{H}, \mathrm{N}=\mathrm{CCH}_{2}, J=7.6 \mathrm{~Hz}\right), 1.60$ (quintet, $\left.2 \mathrm{H}, \mathrm{N}=\mathrm{CCH}_{2} \mathrm{CH}_{2}, J=7.2 \mathrm{~Hz}\right), 1.31-1.26\left(\mathrm{~m}, 4 \mathrm{H}, \mathrm{CH}_{3} \mathrm{CH}_{2} \mathrm{CH}_{2}\right), 0.85\left(\mathrm{t}, 3 \mathrm{H}, \mathrm{CH}_{3}, J=6.8 \mathrm{~Hz}\right) . \mathrm{MS} \mathrm{m} / \mathrm{z}$ (\%): $353\left(\mathrm{M}^{+} ;\right.$4.0). Anal. Calcd. for $\mathrm{C}_{20} \mathrm{H}_{20} \mathrm{ClN}_{3} \mathrm{O}$ (353.85): $\mathrm{C}, 67.89 ; \mathrm{H}, 5.70 ; \mathrm{Cl}, 10.02 ; \mathrm{N}, 11.88$. Found: C, 67.78; $\mathrm{H}, 5.62 ; \mathrm{Cl}, 9.89 ; \mathrm{N}, 11.79$.

\section{3-((4-Methoxybenzylidene)amino)-2-pentylquinazolin-4(3H)-one 11b}

White crystals; m.p.: $83-84^{\circ} \mathrm{C}$ (petroleum ether $60-80{ }^{\circ} \mathrm{C}$ ), yield: $64 \%$. IR $\left(\mathrm{KBr}, \mathrm{cm}^{-1}\right): 2946,2912$, 2882, $2843\left(\mathrm{CH}_{\text {aliph. }}\right), 1669(\mathrm{C}=\mathrm{O}), 1606(\mathrm{C}=\mathrm{N}$ or $\mathrm{C}=\mathrm{C}) .{ }^{1} \mathrm{H}-\mathrm{NMR}\left(400 \mathrm{MHz}, \mathrm{DMSO}-d_{6}\right) \delta(\mathrm{ppm}): 8.81(\mathrm{~s}$, $1 \mathrm{H}, \mathrm{N}=\mathrm{CH}), 8.12\left(\mathrm{~d}, 1 \mathrm{H}, \mathrm{Ar}-\mathrm{H}, \mathrm{H}_{\mathrm{a}}, J=7.8 \mathrm{~Hz}\right), 7.89\left(\mathrm{~d}, 2 \mathrm{H}, \mathrm{Ar}-\mathrm{H}, \mathrm{H}_{\mathrm{E}}+\mathrm{H}_{\mathrm{F}}, J=8.8 \mathrm{~Hz}\right), 7.80(\mathrm{t}, 1 \mathrm{H}$, $\left.\mathrm{Ar}-\mathrm{H}, \mathrm{H}_{\mathrm{c}}, J=8.2, \mathrm{~Hz}, J=7.4 \mathrm{~Hz}\right), 7.65\left(\mathrm{~d}, 1 \mathrm{H}, \mathrm{Ar}-\mathrm{H}, \mathrm{H}_{\mathrm{d}}, J=8.0 \mathrm{~Hz}\right), 7.50\left(\mathrm{t}, 1 \mathrm{H}, \mathrm{Ar}-\mathrm{H}, \mathrm{H}_{\mathrm{b}}, J=7.6, \mathrm{~Hz}\right.$, $J=7.4 \mathrm{~Hz}), 7.12\left(\mathrm{~d}, 2 \mathrm{H}, \mathrm{Ar}-\mathrm{H}, \mathrm{H}_{\mathrm{X}}+\mathrm{H}_{\mathrm{Z}}, J=8.8 \mathrm{~Hz}\right), 3.85\left(\mathrm{~s}, 3 \mathrm{H}, \mathrm{OCH}_{3}\right), 2.80\left(\mathrm{t}, 2 \mathrm{H}, \mathrm{N}=\mathrm{CCH}_{2}, J=7.6 \mathrm{~Hz}\right.$, $J=8.0 \mathrm{~Hz}$ ), 1.71 (quintet, $\left.2 \mathrm{H}, \mathrm{N}=\mathrm{CCH}_{2} \mathrm{CH}_{2}, J=7.6 \mathrm{~Hz}, J=7.2 \mathrm{~Hz}\right), 1.33-1.26\left(\mathrm{~m}, 4 \mathrm{H}, \mathrm{CH}_{3} \mathrm{CH}_{2} \mathrm{CH}_{2}\right.$ ),

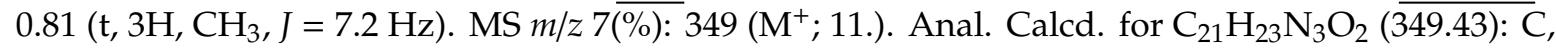
72.18; H, 6.63; N, 12.03. Found: C, 72.29; H, 6.69; N, 11.88 .

\section{3-((3-Hydroxy-4-methoxybenzylidene)amino)-2-pentylquinazolin-4(3H)-one 11c}

White crystals; m.p.: $150-152{ }^{\circ} \mathrm{C}$ (ethanol), yield: $57 \%$. IR (KBr, $\left.\mathrm{cm}^{-1}\right): 3277(\mathrm{OH}), 2956,2927$, 2892, 2863, $2845\left(\mathrm{CH}_{\text {aliph. }}\right), 1678$ (C=O), 1603 (C=N or $\left.\mathrm{C}=\mathrm{C}\right) .{ }^{1} \mathrm{H}-\mathrm{NMR}\left(400 \mathrm{MHz}, \mathrm{DMSO}-d_{6}\right) \delta(\mathrm{ppm})$ : $9.49\left(\mathrm{~s}, 1 \mathrm{H}, \mathrm{OH}\right.$, exchangeable with $\left.\mathrm{D}_{2} \mathrm{O}\right), 8.70(\mathrm{~s}, 1 \mathrm{H}, \mathrm{N}=\mathrm{CH}), 8.12\left(\mathrm{~d}, 1 \mathrm{H}, \mathrm{Ar}-\mathrm{H}, \mathrm{H}_{\mathrm{a}}, J=8.0 \mathrm{~Hz}\right), 7.79(\mathrm{t}$, $\left.1 \mathrm{H}, \mathrm{Ar}-\mathrm{H}, \mathrm{H}_{\mathrm{c}}, J=8.0 \mathrm{~Hz}, J=8.4 \mathrm{~Hz}\right), 7.65\left(\mathrm{~d}, 1 \mathrm{H}, \mathrm{Ar}-\mathrm{H}, \mathrm{H}_{\mathrm{d}}, J=7.6 \mathrm{~Hz}\right), 7.49\left(\mathrm{t}, 1 \mathrm{H}, \mathrm{Ar}-\mathrm{H}, \mathrm{H}_{\mathrm{b}}, J=8.0 \mathrm{~Hz}\right.$, $J=7.2 \mathrm{~Hz}), 7.42\left(\mathrm{~d}, 1 \mathrm{H}, \mathrm{H}_{\mathrm{F}}, J_{m}=2 \mathrm{~Hz}\right), 7.30,7.28\left(\mathrm{~d}, \mathrm{~d}, 1 \mathrm{H}, \mathrm{Ar}-\mathrm{H}, \mathrm{H}_{\mathrm{E}}, J_{o}=8.4 \mathrm{~Hz}, J_{m}=2 \mathrm{~Hz}\right), 7.07(\mathrm{~d}$, $\left.1 \mathrm{H}, \mathrm{Ar}-\mathrm{H}, \mathrm{H}_{\mathrm{X}}, J=8.4 \mathrm{~Hz}\right), 3.85\left(\mathrm{~s}, 3 \mathrm{H}, \mathrm{OCH}_{3}\right), 2.78\left(\mathrm{t}, 2 \mathrm{H}, \mathrm{N}=\mathrm{CCH}_{2}, J=7.6 \mathrm{~Hz}\right), 1.71$ (quintet, $2 \mathrm{H}$, $\left.\mathrm{N}=\mathrm{CCH}_{2} \mathrm{CH}_{2}, J=7.6 \mathrm{~Hz}, J=7.2 \mathrm{~Hz}\right), 1.31-1.28\left(\mathrm{~m}, 4 \mathrm{H}, \mathrm{CH}_{3} \mathrm{CH}_{2} \mathrm{CH}_{2}\right), 0.81\left(\mathrm{t}, 3 \mathrm{H}, \mathrm{CH}_{3}, J=6.8 \mathrm{~Hz}\right.$, $J=7.2 \mathrm{~Hz}) . \mathrm{MS} m / z(\%): 365\left(\mathrm{M}^{+} ; 23.4\right)$. Anal. Calcd. for $\mathrm{C}_{21} \overline{\mathrm{H}_{23} \mathrm{~N}_{3} \mathrm{O}_{3}}(365.43): \mathrm{C}, 69.02 ; \mathrm{H}, 6.34 ; \mathrm{N}$, 11.50. Found: $\mathrm{C}, 68.88 ; \mathrm{H}, 6.28 ; \mathrm{N}, 11.62$.

\section{3-((4-Hydroxy-3,5-dimethoxybenzylidene)amino)-2-pentylquinazolin-4(3H)-one 11d}

White crystals; m.p.: $148-150{ }^{\circ} \mathrm{C}$ (benzene), yield: 61\%. IR (KBr, $\left.\mathrm{cm}^{-1}\right)$ : $3408(\mathrm{OH}), 2952,2911$, $2844\left(\mathrm{CH}_{\text {aliph. }}\right), 1668(\mathrm{C}=\mathrm{O}), 1591(\mathrm{C}=\mathrm{N}$ or $\mathrm{C}=\mathrm{C}) .{ }^{1} \mathrm{H}-\mathrm{NMR}\left(400 \mathrm{MHz}, \mathrm{DMSO}-\mathrm{d}_{6}\right) \delta$ (ppm): 9.36 (br.s, $1 \mathrm{H}, \mathrm{OH}$, exchangeable with $\left.\mathrm{D}_{2} \mathrm{O}\right), 8.72(\mathrm{~s}, 1 \mathrm{H}, \mathrm{N}=\mathrm{CH}), 8.12\left(\mathrm{~d}, 1 \mathrm{H}, \mathrm{Ar}-\mathrm{H}, \mathrm{H}_{\mathrm{a}}, J=8.2 \mathrm{~Hz}\right), 7.79(\mathrm{t}, 1 \mathrm{H}$, $\left.\mathrm{Ar}-\mathrm{H}, \mathrm{H}_{\mathrm{c}}, J=8.0 \mathrm{~Hz}, J=7.4 \mathrm{~Hz}\right), 7.65\left(\mathrm{~d}, 1 \mathrm{H}, \mathrm{Ar}-\mathrm{H}, \mathrm{H}_{\mathrm{d}}, J=7.6 \mathrm{~Hz}\right), 7.50\left(\mathrm{t}, 1 \mathrm{H}, \mathrm{Ar}-\mathrm{H}, \mathrm{H}_{\mathrm{b}}, J=8.0 \mathrm{~Hz}\right.$, $J=7.2 \mathrm{~Hz}), 7.23\left(\mathrm{~s}, 2 \mathrm{H}, \mathrm{H}_{\mathrm{E}}+\mathrm{H}_{\mathrm{F}}\right), 3.82\left(\mathrm{~s}, 6 \mathrm{H}, 2 \mathrm{OCH}_{3}\right), 2.81\left(\mathrm{t}, 2 \mathrm{H}, \mathrm{N}=\mathrm{CCH}_{2}, J=7.6 \mathrm{~Hz}, J=8.0 \mathrm{~Hz}\right), 1.72$ (quintet, $\left.2 \mathrm{H}, \mathrm{N}=\mathrm{CCH}_{2} \mathrm{CH}_{2}, J=7.6 \mathrm{~Hz}, J=7.2 \mathrm{~Hz}\right), 1.36-1.26\left(\mathrm{~m}, 4 \mathrm{H}, \mathrm{CH}_{3} \mathrm{CH}_{2} \mathrm{CH}_{2}\right), 0.81\left(\mathrm{t}, 3 \mathrm{H}, \mathrm{CH}_{3}\right.$, $J=6.8 \mathrm{~Hz}, J=7.2 \mathrm{~Hz}) .{ }^{13} \mathrm{C}-\mathrm{NMR}\left(100 \mathrm{MHz}, \mathrm{DMSO}-d_{6}\right) \delta(\mathrm{ppm}): 169.8, \overline{158.0,156.5}, 148.6(2), 146.7$, 140.8, 134.6, 127.4, 127.0, 126.7, 122.8, 121.3, 106.8 (2), 56.5 (2), 34.5, 31.3, 26.0, 22.2, 14.2. MS m/z (\%): $395\left(\mathrm{M}^{+} ; 62.1\right)$, Anal. Calcd. for $\mathrm{C}_{22} \mathrm{H}_{25} \mathrm{~N}_{3} \mathrm{O}_{4}$ (395.46): $\mathrm{C}, 66.82 ; \mathrm{H}, 6.37 ; \mathrm{N}, 10.63$. Found: $\mathrm{C}, 66.95 ; \mathrm{H}$, $6.41 ; \mathrm{N}, 10.58$.

\subsubsection{2-(4-Chlorophenyl)-3-(4-oxo-2-pentylquinazolin-3(4H)-yl)thiazolidin-4-one 12}

A mixture of compound 11a $(3.53 \mathrm{~g}, 0.01 \mathrm{~mol})$ and methyl thioglycolate $(0.89 \mathrm{~mL}, 0.01 \mathrm{~mol})$ in absolute ethanol $(30 \mathrm{~mL})$ containing piperidine $(0.5 \mathrm{~mL})$ was refluxed for $3 \mathrm{~h}$. The obtained solid after evaporation of the solvent was collected and recrystallized from petroleum ether $60-80{ }^{\circ} \mathrm{C}$ to give 12 as pale yellow crystals; m.p.: $78-80{ }^{\circ} \mathrm{C}$, yield: $47 \%$. IR $\left(\mathrm{KBr}, \mathrm{cm}^{-1}\right): 2951,2925,2868\left(\mathrm{CH}_{\text {aliph. }}\right)$, $1736\left(\mathrm{C}=\mathrm{O}_{\text {thiazolidinone }}\right), 1671\left(\mathrm{C}=\mathrm{O}_{\text {quinazolinone }}\right), 1608(\mathrm{C}=\mathrm{N}$ or $\mathrm{C}=\mathrm{C}) .{ }^{1} \mathrm{H}-\mathrm{NMR}\left(100 \mathrm{MHz}, \mathrm{DMSO}-d_{6}\right) \delta$ (ppm): $8.13\left(\mathrm{~d}, 1 \mathrm{H}, \mathrm{Ar}-\mathrm{H}, \mathrm{H}_{\mathrm{a}}, J=8.2 \mathrm{~Hz}\right), 7.96\left(\mathrm{~d}, 2 \mathrm{H}, \mathrm{Ar}-\mathrm{H}, \mathrm{H}_{\mathrm{E}}+\mathrm{H}_{\mathrm{F}}, J=8.0 \mathrm{~Hz}\right), 7.80(\mathrm{t}, 1 \mathrm{H}, \mathrm{Ar}-\mathrm{H}$, 
$\left.\mathrm{H}_{\mathrm{c}}, J=7.6 \mathrm{~Hz}\right), 7.65\left(\mathrm{~d}, 1 \mathrm{H}, \mathrm{Ar}-\mathrm{H}, \mathrm{H}_{\mathrm{d}}, J=8.0 \mathrm{~Hz}\right), 7.64\left(\mathrm{~d}, 2 \mathrm{H}, \mathrm{Ar}-\mathrm{H}, \mathrm{H}_{\mathrm{X}}+\mathrm{H}_{\mathrm{Z}}, J=8.4 \mathrm{~Hz}\right), 7.51(\mathrm{t}, 1 \mathrm{H}$, $\left.\mathrm{Ar}-\mathrm{H}, \mathrm{H}_{\mathrm{b}}, J=7.6 \mathrm{~Hz}, J=7.8 \mathrm{~Hz}\right), 5.70(\mathrm{~s}, 1 \mathrm{H}, \mathrm{SCH}), 3.75,3.67\left(\mathrm{~d}, \mathrm{~d}, 2 \mathrm{H}, \mathrm{CH}_{2 \text { (thiazolidinone) }}, J=23.6 \mathrm{~Hz}\right.$, $J=23.2 \mathrm{~Hz}$ ), $2.81\left(\mathrm{t}, 2 \mathrm{H}, \mathrm{N}=\mathrm{CCH}_{2}, J=8.0 \mathrm{~Hz}, J=7.6 \mathrm{~Hz}\right.$ ), 1.71 (quintet, $2 \mathrm{H}, \mathrm{N}=\mathrm{CCH}_{2} \mathrm{CH}_{2}, J=7.6 \mathrm{~Hz}$, $J=8.0 \mathrm{~Hz}), 1.35-1.17\left(\mathrm{~m}, 4 \mathrm{H}, \mathrm{CH}_{3} \mathrm{CH}_{2} \mathrm{CH}_{2}\right), 0.80\left(\mathrm{t}, 3 \mathrm{H}, \mathrm{CH}_{3}, J=7.2 \mathrm{~Hz}\right) . \mathrm{MS} m / z(\%): 427\left(\mathrm{M}^{+} ; 11.8\right)$. Anal. Calcd. for $\mathrm{C}_{22} \mathrm{H}_{22} \mathrm{ClN}_{3} \mathrm{O}_{2} \mathrm{~S}$ (427.95): $\mathrm{C}, 61.75 ; \mathrm{H}, 5.18 ; \mathrm{Cl}, 8.28 ; \mathrm{N}, 9.82 ; \mathrm{S}, 7.49$. Found: $\mathrm{C}, 61.66$; $\mathrm{H}, 5.12 ; \mathrm{Cl}, 8.31 ; \mathrm{N}, 9.75 ; \mathrm{S}, 7.55$.

\subsubsection{4,5,6,7-Tetrachloro-2-(4-oxo-2-pentylquinazolin-3(4H)-yl)isoindoline-1,3-dione 13}

Compound 9 ( $2.31 \mathrm{~g}, 0.01 \mathrm{~mol})$ was fused with 4,5,6,7-tetrachloroisobenzofuran-1,3-dione ( $2.85 \mathrm{~g}$, $0.01 \mathrm{~mol}$ ) in oil bath for an hour. The resulting solid was recrystallized from ethanol to give $\mathbf{1 3}$ as orange crystals; m.p.: $178-180{ }^{\circ} \mathrm{C}$, yield: $86 \%$. IR $\left(\mathrm{KBr}, \mathrm{cm}^{-1}\right): 2943,2856\left(\mathrm{CH}_{\text {aliph. }}\right), 1788,1746\left(\mathrm{C}=\mathrm{O}_{\text {imide }}\right)$, $1705\left(\mathrm{C}=\mathrm{O}_{\text {quinazolinone }}\right), 1606(\mathrm{C}=\mathrm{N}$ or $\mathrm{C}=\mathrm{C}) .{ }^{1} \mathrm{H}-\mathrm{NMR}\left(400 \mathrm{MHz}, \mathrm{DMSO}-d_{6}\right) \delta(\mathrm{ppm}): 8.08(\mathrm{~d}, 1 \mathrm{H}$, $\left.\mathrm{Ar}-\mathrm{H}, \mathrm{H}_{\mathrm{a}}, J=8 \mathrm{~Hz}\right), 7.94\left(\mathrm{t}, 1 \mathrm{H}, \mathrm{Ar}-\mathrm{H}, \mathrm{H}_{\mathrm{c}}, J=8.0 \mathrm{~Hz}, J=7.2 \mathrm{~Hz}\right), 7.76\left(\mathrm{~d}, 1 \mathrm{H}, \mathrm{Ar}-\mathrm{H}, \mathrm{H}_{\mathrm{d}}, J=8.0 \mathrm{~Hz}\right)$, $7.60\left(\mathrm{t}, 1 \mathrm{H}, \mathrm{Ar}-\mathrm{H}, \mathrm{H}_{\mathrm{b}}, J=7.6 \mathrm{~Hz}\right), 2.73\left(\mathrm{t}, 2 \mathrm{H}, \mathrm{N}=\mathrm{CCH}_{2}, J=6.8 \mathrm{~Hz}, J=8.0 \mathrm{~Hz}\right), 1.70-1.60(\mathrm{~m}, 2 \mathrm{H}$, $\left.\mathrm{N}=\mathrm{CCH}_{2} \mathrm{CH}_{2}\right), 1.29-1.27\left(\mathrm{~m}, 4 \mathrm{H}, \mathrm{CH}_{3} \mathrm{CH}_{2} \mathrm{CH}_{2}\right), 0.81\left(\mathrm{t}, 3 \mathrm{H}, \mathrm{CH}_{3}, J=6.8 \mathrm{~Hz}, J=7.2 \mathrm{~Hz}\right) .{ }^{13} \mathrm{C}-\mathrm{NMR}$ $\left(100 \mathrm{MHz}, \mathrm{DMSO}-d_{6}\right) \delta$ (ppm): 161.5, 161.3, 157.9, 157.7, 147.4, 146.7, 140.0, 138.8, 136.6 (2), 128.2 (2), 128.0, 127.1, 126.8, 119.8, 32.6, 30.9, 26.0, 22.2, 14.2. MS m/z (\%): $231\left(\mathrm{M}^{+} ; 41.1\right)$. Anal. Calcd. for $\mathrm{C}_{21} \mathrm{H}_{15} \mathrm{C}_{14} \mathrm{~N}_{3} \mathrm{O}_{3}$ (499.17): C, 50.53; H, 3.03; $\mathrm{Cl}, 28.41 ; \mathrm{N}, 8.42$. Found: $\mathrm{C}, 50.61 ; \mathrm{H}, 3.09 ; \mathrm{Cl}, 28.37 ; \mathrm{N}, 8.53$.

\subsubsection{3-Amino-2-pentylquinazoline-4(3H)-thione 14}

A mixture of compound $9(2.31 \mathrm{~g}, 0.01 \mathrm{~mol})$ and $\mathrm{P}_{2} \mathrm{~S}_{5}(2.22 \mathrm{~g}, 0.01 \mathrm{~mol})$ in dry toluene $(15 \mathrm{~mL})$ was heated under reflux for $4 \mathrm{~h}$. The mixture was filtered off, the filtrate was evaporated under reduced pressure, the obtained solid was collected, dried, and recrystallized from ethanol to give $\mathbf{1 4}$ as yellow crystals; m.p.: $57-59^{\circ} \mathrm{C}$, yield: $53 \%$. IR $\left(\mathrm{KBr}, \mathrm{cm}^{-1}\right)$ : 3240, $3200\left(\mathrm{NH}_{2}\right), 2925,2855\left(\mathrm{CH}_{\text {aliph. }}\right), 1591$ $(\mathrm{C}=\mathrm{N}$ or $\mathrm{C}=\mathrm{C}), 1238(\mathrm{C}=\mathrm{S}) .{ }^{1} \mathrm{H}-\mathrm{NMR}\left(400 \mathrm{MHz}, \mathrm{DMSO}-d_{6}\right) \delta(\mathrm{ppm}): 8.51\left(\mathrm{~d}, 1 \mathrm{H}, \mathrm{Ar}-\mathrm{H}, \mathrm{H}_{\mathrm{a}}, J=8.2 \mathrm{~Hz}\right)$, $7.82\left(\mathrm{t}, 1 \mathrm{H}, \mathrm{Ar}-\mathrm{H}, \mathrm{H}_{\mathrm{c}}, J=7.6 \mathrm{~Hz}, J=7.8 \mathrm{~Hz}\right), 7.69\left(\mathrm{~d}, 1 \mathrm{H}, \mathrm{Ar}-\mathrm{H}, \mathrm{H}_{\mathrm{d}}, J=7.6 \mathrm{~Hz}\right), 7.57\left(\mathrm{t}, 1 \mathrm{H}, \mathrm{Ar}-\mathrm{H}, \mathrm{H}_{\mathrm{b}}\right.$, $J=7.6 \mathrm{~Hz}), 7.04\left(\mathrm{~s}, 2 \mathrm{H}, \mathrm{NH}_{2}\right.$, exchangeable with $\left.\mathrm{D}_{2} \mathrm{O}\right), 3.06\left(\mathrm{t}, 2 \mathrm{H}, \mathrm{N}=\mathrm{CCH}_{2}, J=7.2 \mathrm{~Hz}, J=8.0 \mathrm{~Hz}\right)$, 1.81 (quintet, $\left.2 \mathrm{H}, \mathrm{N}=\mathrm{CCH}_{2} \mathrm{CH}_{2}, J=7.6 \mathrm{~Hz}, J=7.2 \mathrm{~Hz}\right), 1.42-1.32\left(\mathrm{~m}, 4 \mathrm{H}, \mathrm{CH}_{3} \mathrm{CH}_{2} \mathrm{CH}_{2}\right), 0.88(\mathrm{t}, 3 \mathrm{H}$, $\left.\mathrm{CH}_{3}, J=6.8 \mathrm{~Hz}, J=7.2 \mathrm{~Hz}\right) .{ }^{13} \mathrm{C}$ NMR $\left(100 \mathrm{MHz}, \mathrm{DMSO}-d_{6}\right) \delta(\mathrm{ppm}): 182.1,155.5,142.0,134.5,130.6$, 128.1 (2), 127.4, 34.4, 31.3, 25.5, 22.4, 14.3. MS m/z (\%): $247\left(\mathrm{M}^{+} ; 74.3\right)$. Anal. Calcd. for $\mathrm{C}_{13} \mathrm{H}_{17} \mathrm{~N}_{3} \mathrm{~S}$ (247.36): C, 63.12; H, 6.93; N, 16.99; S, 12.96. Found: C, 63.19; H, 6.96; N, 17.11; S, 12.82.

\subsection{Cytotoxicity and Antiproliferative Evaluation}

\section{MTT Assay}

The implement of MTT methodology for the antiproliferative screening of quinazolinone derivatives 5-14 along with compound 3 against two cell lines, namely, hepatocellular carcinoma (HepG2) and mammary gland (MCF-7) were obtained from ATCC through the Holding company for biological products and vaccines (VACSERA), Cairo, Egypt. The reference anticancer drug used was Doxorubicin. The MTT assay was carried out at the pharmacology department, Faculty of pharmacy, Mansoura University, Egypt according to the reported literatures $[42,43,54]$. The cells were cultured in a RPMI-1640 medium with 10\% fetal bovine serum, followed by the addition of antibiotics (100 units $/ \mathrm{mL}$ penicillin and $100 \mu \mathrm{g} / \mathrm{mL}$ streptomycin) at $37^{\circ} \mathrm{C}$ in a $5 \% \mathrm{CO}_{2}$ incubator. The cells were seeded in a 96-well plate at a density of $\left(1.0 \times 10^{4}\right.$ cells/well $)$ at $37^{\circ} \mathrm{C}$ for $48 \mathrm{~h}$ under $5 \% \mathrm{CO}_{2}$. Treatment of cells with different concentrations of compounds such as $100,50,25,12.5,6.25,3.125$, and $1.56 \mu \mathrm{M}$ was carried out and placed in the incubator for $24 \mathrm{~h}$. Then, $20 \mu \mathrm{L}$ of MTT solution at $5 \mathrm{mg} / \mathrm{mL}$ was added and incubated for $4 \mathrm{~h}$. DMSO $(100 \mu \mathrm{L})$ was added into each well to dissolve the purple formazan formed. At $570 \mathrm{~nm}$ absorbance the colorimetric assay was measured and recorded by using a plate reader (BioTek EL ×800 Microplate Reader, BioTek Instruments, Inc, Winooski, VT, USA).

Calculation of the relative cell viability $(\%)=($ A of treated samples $/ \mathrm{A}$ of untreated sample $) \times 100$. 


\subsection{Antioxidant Assay}

\subsubsection{Antioxidant Activity Screening Assay}

\section{ABTS Method}

By the bleaching of ABTS derived radical cations, the detections of antioxidant activities were estimated. The radical cation was prepared by the reaction of ABTS [2,2'-azino-bis(3-ethyl benzothiazoline-6-sulfonic acid)] $(60 \mu \mathrm{L})$ with $\mathrm{MnO}_{2}(3 \mathrm{~mL}, 25 \mathrm{mg} / \mathrm{mL})$ in a phosphate buffer solution $(10 \mu \mathrm{M}, \mathrm{pH} 7,5 \mathrm{~mL})$. The solution was shaken for $3 \mathrm{~min}$, centrifuged, filtered, and recorded at $\lambda_{\max }$ $734 \mathrm{~nm}$ the absorbance $A_{\text {(control) }}$ of the resulting ABTS radical solution (green-blue). Upon the addition of the tested sample solution $(20 \mu \mathrm{l})$ with different concentrations of compounds such as 200, 100, 50, 25, and $12.5 \mu \mathrm{M}$ in spectroscopic grade $\mathrm{MeOH} / \mathrm{buffer}(1: 1 v / v)$ to the ABTS solution, the absorbance $A_{\text {(test) }}$ was measured. The decreasing in the absorbance is expressed as \% inhibition which was calculated according to the following equation [55]:

$$
\% \text { Inhibition }=\left[A_{\text {(control) }}-A_{(\text {test })} / A_{(\text {control })}\right] \times 100
$$

where; the reference and standard antioxidant compound in this test is the ascorbic acid solution $(20 \mu \mathrm{L}, 2 \mathrm{mM})$ and the blank sample was performed by the solvent without ABTS.

\section{DPPH Method}

According to the methodology described by Brand-Williams et al. [56], the measurement of the DPPH radical scavenging activity was implemented. The samples with different concentrations of compounds such as $200,100,50,25$, and $12.5 \mu \mathrm{M}$ were allowed to react with the stable DPPH radical in ethanol solution. Whereas, the reaction mixture consisted of sample $(0.5 \mathrm{~mL})$, absolute ethanol $(3 \mathrm{~mL})$, and DPPH radical solution $(0.3 \mathrm{~mL}) 0.5 \mathrm{mM}$ in ethanol. DPPH is reduced when it reacts with an antioxidant compound, which can donate hydrogen. The changes in color (from deep violet to light yellow) were recorded [absorbance $(A b s)$ ] at $\lambda_{\max } 517 \mathrm{~nm}$ after $100 \mathrm{~min}$ of reaction using a UV-Vis spectrophotometer (Schimadzu Co., Tokyo, Japan). The blank solution was prepared by mixing ethanol $(3.3 \mathrm{~mL})$ and the sample $(0.5 \mathrm{~mL})$. Meanwhile, the mixture of ethanol $(3.5 \mathrm{~mL})$ and DPPH radical solution $(0.3 \mathrm{~mL})$ serve as a positive control.

The scavenging activity percentage $(A A \%)$ was determined according to Mensor et al. [57]:

$$
A A \%=100-\left[\left(A b s_{(\text {sample })}-A b s_{(\text {blankl })} / A b s_{(\text {control })}\right) \times 100\right]
$$

\subsection{Computational Procedures}

All theoretical calculations and results of the studied compounds were implemented by utilizing Gaussian(R) 09 D. 01 [58] (Semichem Inc., Shawnee Mission, KS, USA) by applying the DFT operation with the hybrid functional B3LYP level $[59,60]$ in conjunction with the $6-31 \mathrm{G}(\mathrm{d}, \mathrm{p})$ basis set. The visualization of these results was achieved using GaussView 6.0.16 software (Semichem Inc., Shawnee Mission, KS, USA).

\section{Conclusions}

In conclusion, this work focused on the study of the antiproliferative and antioxidant activities in vitro in addition to the theoretical calculation of the DFT theory of some novel quinazolinone(thione) derivatives 6-14. Two main points were the principal targets; firstly, by comparing the activities of quinazolinone and quinazolinthione derivatives. Secondly, comparing the activities of four series of Schiff bases, that have quinazolinone moiety. The results of this study imply that the quinazolinthione derivatives $\mathbf{6}$ and $\mathbf{1 4}$ have promising potent antiproliferative activity comparable with quinazolinone derivatives $\mathbf{5}$ and $\mathbf{9}$, respectively. According to the DFT study, compounds $\mathbf{6}$ and $\mathbf{1 4}$ have a smaller 
energy gap and a higher chemical softness than that of compounds $\mathbf{5}$ and $\mathbf{9}$, respectively. Additionally, screening of various aryl aldehyde hydrazone derivatives (11a-d) analogs exhibited that the potency increased with increasing the electron donating group in $p$-position due to increasing of the conjugated system, and that was supported by the DFT study.

On the other hand, compounds 6 and 11d showed promising antioxidant activity using ABTS assay. While in the DPPH assay, compounds 6, 11d, and $\mathbf{1 4}$ have showed potent activities comparable to the ascorbic acid which was used as a reference drug. Noteworthy, the results of both antiproliferative and antioxidant activities for each compound individually are nearly the same.

Author Contributions: The listed authors contributed to this work as described in the following: A.A.E.-S., M.F.I., and A.E.-G.E.A. designed the research idea, implemented the synthesis and characterization of novel compounds, and contributed to the data interpretation. A.E.-G.E.A. and A.M.N. contributed to discuss the results, writing the original draft manuscript, and revisions. All authors read and approved the final manuscript.

Funding: The authors are grateful to the Deanship of Scientific Research, King Saud University for funding this work through research group project "RGP-172".

Conflicts of Interest: The authors declare no conflict of interest.

\section{References}

1. Stewart, B.W.; Wild, C.P. (Eds.) World Cancer Report; International Agency for Research on Cancer: Lyon, France, 2014.

2. Spanò, V.; Montalbano, A.; Carbone, A.; Parrino, B.; Diana, P.; Cirrincione, G.; Castagliuolo, I.; Brun, P.; Issinger, O.G.; Tisi, S.; et al. Synthesis of a new class of pyrrolo[3,4-h]quinazolines with antimitotic activity. Eur. J. Med. Chem. 2014, 74, 340-357. [CrossRef] [PubMed]

3. Sordella, R.; Bell, D.W.; Haber, D.A.; Settleman, J. Gefitinib-sensitizing EGFR mutations in lung cancer activate anti-apoptotic pathways. Science 2004, 305, 1163-1167. [CrossRef] [PubMed]

4. Raymond, E.; Faivre, S.; Armand, J.P. Epidermal growth factor receptor tyrosine kinase as a target for anticancer therapy. Drugs 2000, 60, 15-23. [CrossRef] [PubMed]

5. Ko, H.C.; Wang, Y.H.; Liou, K.T.; Chen, C.M.; Chen, C.H.; Wang, W.Y.; Chang, S.; Hou, Y.C.; Chen, K.T.; Chen, C.F.; et al. Antiinflammatory effects and mechanisms of the ethanol extract of Evodia rutaecarpa and its bioactive components on neutrophils and microglial cells. Eur. J. Pharmacol. 2007, 555, 211-217. [CrossRef] [PubMed]

6. Keller, T.L.; Zocco, D.; Sundrud, M.S.; Hendrick, M.; Edenius, M.; Yum, J.; Kim, Y.J.; Lee, H.K.; Cortese, J.F.; Wirth, D.F.; et al. Halofuginone and other febrifugine derivatives inhibit prolyl-tRNA synthetase. Nat. Chem. Biol. 2012, 8, 311-317. [CrossRef]

7. El-Azab, A.S.; Eltahir, K.E. Synthesis and anticonvulsant evaluation of some new 2,3,8-trisubstituted-4(3H)-quinazoline derivatives. Bioorg. Med. Chem. Lett. 2012, 22, 327-333. [CrossRef]

8. Shcherbakova, I.; Balandrin, M.F.; Fox, J.; Ghatak, A.; Heaton, W.L.; Conklin, R.L. 3H-Quinazolin-4-ones as a new calcilytic template for the potential treatment of osteoporosis. Bioorg. Med. Chem. Lett. 2005, 15, 1557-1560. [CrossRef]

9. Reddy, A.G.; Babu, V.H.; Rao, Y.J.P. A review on quinazolines as anticancer agents. J. Chem. Pharm.Sci. 2017, 10, 1492-1504.

10. Mohamed, M.A.; Ayyad, R.R.; Shawer, T.Z.; Abdel-Aziz, A.A.-M.; El-Azab, A.S. Synthesis and antitumor evaluation of trimethoxyanilides based on 4(3H)-quinazolinone scaffolds. Eur. J. Med. Chem. 2016, 112, 106-113. [CrossRef]

11. Chinigo, G.M.; Paige, M.; Grindrod, S.; Hamel, E.; Dakshanamurthy, S.; Chruszcz, M.; Minor, W.; Brown, M.L. Asymmetric synthesis of 2,3-dihydro-2-arylquinazolin-4-ones: methodology and application to a potent fluorescent tubulin inhibitor with anticancer activity. J. Med. Chem. 2008, 51, 4620-4631. [CrossRef]

12. Kubo, K.; Shimizu, T.; Ohyama, S.; Murooka, H.; Iwai, A.; Nakamura, K.; Hasegawa, K.; Kobayashi, Y.; Takahashi, N.; Takahashi, K.; et al. Novel potent orally active selective VEGFR-2 tyrosine kinase inhibitors: synthesis, structure-activity relationships, and antitumor activities of N-phenyl-N'-\{4-(4-quinolyloxy)phenyl\}ureas. J. Med. Chem. 2005, 48, 1359-1366. [CrossRef] [PubMed] 
13. Hour, M.-J.; Huang, L.-J.; Kuo, S.-C.; Xia, Y.; Bastow, K.; Nakanishi, Y.; Hamel, E.; Lee, K.-H. 6-Alkylamino- and 2,3-Dihydro-3'-methoxy-2-phenyl-4-quinazolinones and related compounds: Their synthesis, cytotoxicity, and inhibition of tubulin polymerization. J. Med. Chem. 2000, 43, 4479-4487. [CrossRef] [PubMed]

14. Takase, Y.; Saeki, T.; Watanabe, N.; Adachi, H.; Souda, S.; Saito, I. Cyclic GMP Phosphodiesterase inhibitors. 2. requirement of 6-substitution of quinazoline derivatives for potent and selective inhibitory activity. J. Med. Chem. 1994, 37, 2106-2111. [CrossRef] [PubMed]

15. Khodarahmi, G.; Jafari, E.; Hakimelahi, G.; Abedi, D.; Rahmani, K.M.; Hassanzadeh, F. Synthesis of some new quinazolinone derivatives and evaluation of their antimicrobial activities. Iran, J. Pharm. Res. 2012, 11, 789-797.

16. Venkatesh, R.; Kasaboina, S.; Jain, N.; Janardhan, S.; Holagunda, U.D.; Nagarapu, L. Design and synthesis of novel sulphamide tethered quinazolinone hybrids as potential antitumor agents. J. Mol. Struct. 2019, 1181, 403-411. [CrossRef]

17. Patel, M.B.; Kumar, S.P.; Valand, N.N.; Jasrai, Y.T.; Menon, S.K. Synthesis and biological evaluation of cationic fullerene quinazolinone conjugates and their binding mode with modeled Mycobacterium tuberculosis hypoxanthine-guanine phosphoribosyltransferase enzyme. J. Mol. Model. 2013, 19, 3201-3217. [CrossRef]

18. Mhaske, S.B.; Argade, N.P. the chemistry of recently isolated naturally occurring quinazolinone alkaloids. Tetrahedron 2006, 62, 9787-9826. [CrossRef]

19. Song, F.; Ren, B.; Yu, K.; Chen, C.; Guo, H.; Yang, N.; Gao, H.; Liu, X.; Liu, M.; Tong, Y.; et al. Quinazolin-4-one coupled with pyrrolidin-2-iminium alkaloids from marine-derived fungus Penicillium aurantiogriseum. Mar Drugs. 2012, 10, 1297-1306. [CrossRef]

20. Obafemi, C.A.; Fadare, O.A.; Jasinski, J.P.; Millikan, S.P.; Obuotor, E.M.; Iwalewa, E.O.; Famuyiwa, S.O.; Sanusi, K.; Yilmaz, Y.; Ceylan, Ü. Microwave-assisted synthesis, structural characterization, DFT studies, antibacterial and antioxidant activity of 2-methyl-4-oxo-1,2,3,4- tetrahydroquinazoline-2-carboxylic acid. J. Mol. Struct. 2018, 1155, 610-622. [CrossRef]

21. Patel, N.B.; Patel, V.N. New 2,3-disubstituted quinazolin-4 (3H)-ones as antimicrobial agents. Ind. J. Heterocycl. Chem. 2007, 16, 247-250.

22. Peet, N.P.; Baugh, L.E.; Sunder, S.; Lewis, J.E.; Matthews, E.H.; Olberding, E.L.; Shah, D.N. 3-(1H-Tetrazol-5-yl)-4(3H)-quinazolinone sodium salt (MDL 427): A new antiallergic agent. J. Med. Chem. 1986, 29, 2403-2409. [CrossRef] [PubMed]

23. Patil, A.; Barge, M.; Rashinkar, G.; Salunkhe, R. Aqueous hydrotrope: An efficient and reusable medium for a green one-pot, diversity-oriented synthesis of quinazolinone derivatives. Mol. Divers. 2015, 19, 435-445. [CrossRef] [PubMed]

24. Khattab, S.N.; Haiba, N.S.; Asal, A.M.; Bekhit, A.A.; Guemei, A.A.; Amer, A.; El-Faham, A. Study of antileishmanial activity of 2-aminobenzoyl amino acid hydrazides and their quinazoline derivatives. Bioorg. Med. Chem. Lett. 2017, 27, 918-921. [CrossRef] [PubMed]

25. Haghighijoo, Z.; Firuzi, O.; Hemmateenejad, B.; Emami, S.; Edraki, N.; Miri, R. Synthesis and biological evaluation of quinazolinone-based hydrazones with potential use in Alzheimer's disease. Bioorg. Chem. 2017, 74, 126-133. [CrossRef] [PubMed]

26. Mhaske, S.B.; Argade, N.P. Regioselective quinazolinone-directed ortho lithiation of quinazolinoylquinoline: practical synthesis of naturally occurring human DNA topoisomerase I poison luotonin a and luotonins B and E. J. Organomet. Chem. 2004, 69, 4563-4566. [CrossRef]

27. Houck, D.R.; Ondeyka, J.; Zink, D.L.; Inamine, E.; Goetz, M.A.; Hensens, O.D. On the biosynthesis of asperlicin and the directed biosynthesis of analogs in Aspergillus alliaceus. J. Antibiot. (Tokyo) 1988, 41, 882-891. [CrossRef]

28. He, L.; Li, H.; Chen, J.; Wu, X. Recent advances in 4(3H)-quinazolinone syntheses. RSC Adv. 2014, 4, 12065-12077. [CrossRef]

29. Chaudhuri, P.K. Echinozolinone, an alkaloid from Echinops echinatus. Phytochemistry 1987, 26, 587-589. [CrossRef]

30. Ramanathan, M.; Hsu, M.T.; Liu, S.T. Preparation of 4(3H)-quinazolinones from aryldiazonium salt, nitriles and 2-aminobenzoate via a cascade annulation. Tetrahedron 2019, 75, 791-796. [CrossRef]

31. Sales, Z.S.; Mani, N.S.; Allison, B.D. The synthesis of 2-amino-4(3H)-quinazolinones and related heterocycles via a mild electrocyclization of aryl guanidines. Tetrahedron Lett. 2018, 59, 1623-1626. [CrossRef] 
32. Ismail, M.F.; El-sayed, G.A. Dodecanoyl isothiocyanate and N'-(2-cyanoacetyl)dodecane- hydrazide as precursors for the synthesis of different heterocyclic compounds with interesting antioxidant and antitumor activity. Synth. Commun. 2018, 48, 892-905. [CrossRef]

33. Ajani, O.O.; Audu, O.Y.; Aderohunmu, D.V.; Owolabi, F.E.; Olomieja, A.O. Review Article Undeniable Pharmacological Potentials of Quinazoline Motifs in Therapeutic Medicine. Am. J. Drug Discov. Dev. 2017, 7, 1-24. [CrossRef]

34. Abbas, S.Y.; El-Bayouki, K.A.M.; Basyouni, W.M. Utilization of isatoic anhydride in the syntheses of various types of quinazoline and quinazolinone derivatives. Synth. Commun. 2016, 46, 993-1035. [CrossRef]

35. Maiden, T.M.M.; Harrity, J.P.A. Recent developments in transition metal catalysis for quinazolinone synthesis. Org. Biomol. Chem. 2016, 14, 8014-8025. [CrossRef]

36. Rohokale, R.S.; Kshirsagar, U.A. Advanced Synthetic Strategies for Constructing Quinazolinone Scaffolds. Synthesis 2016, 48, 1253-1268. [CrossRef]

37. Youssef, Y.M.; El-Sayed, A.A.; Azab, M.E. Utility of Benzoxazin-4-one and 3-amino- quinazolin-4-one Derivatives as Precursors for Construction of Potent Insecticidal Heterocycles. J. Heterocyclic Chem. 2019. [CrossRef]

38. Park, W.J.; Ma, E. Inhibition of PCAF histone acetyltransferase and cytotoxic effect of $\mathrm{N}$-acylanthranilic acids. Pharmacal. Res. 2012, 35, 1379-1386. [CrossRef]

39. Li, W.; Wu, X.-F. Palladium-catalyzed carbonylative synthesis of benzoxazinones from $N$-(o-Bromoaryl)amides using paraformaldehyde as the carbonyl source. J. Org. Chem. 2014, 79, 10410-10416. [CrossRef]

40. Mahindroo, N.; Ahmed, Z.; Bhagat, A.; Bedi, K.L.; Khajuria, R.K.; Kapoor, V.K.; Dhar, K.L. Synthesis and structure-activity relationships of vasicine analogues as bronchodilatory agents. Med. Chem. Res. 2006, 14, 347-368. [CrossRef]

41. Zhang, W.; Meng, C.; Liu, Y.; Tang, Y.; Li, F. Auto-tandem catalysis with ruthenium: From o-aminobenzamides and allylic alcohols to quinazolinones via redox isomerization/acceptorless dehydrogenation. Adv. Synth. Catal. 2018, 360, 3751-3759. [CrossRef]

42. Mosmann, T. Rapid colorimetric assay for cellular growth and survival: application to proliferation and cytotoxicity assays. J. Immunol. Methods 1983, 65, 55-63. [CrossRef]

43. Denizot, F.; Lang, R. Rapid colorimetric assay for cell growth and survival. Modifications to the tetrazolium dye procedure giving improved sensitivity and reliability. J. Immunol. Methods 1986, 89, 271-277. [CrossRef]

44. He, D.; Wang, M.; Zhao, S.; Shu, Y.; Zeng, H.; Xiao, C.; Lu, C.; Liu, Y. Pharmaceutical prospects of naturally occurring quinazolinone and its derivatives. Fitoterapia 2017, 119, 136-149. [CrossRef] [PubMed]

45. Karunakaran, V.; Balachandran, V. FT-IR, FT-Raman spectra, NBO, HOMO-LUMO and thermodynamic functions of 4-chloro-3-nitrobenzaldehyde based on ab initio HF and DFT calculations. Spectrochim. Acta A 2012, 98, 229-239. [CrossRef] [PubMed]

46. Ayyamperumal, N.; Balachandran, V.; Thangavel, K. Molecular structure, vibrational spectra, first hyperpolarizability and HOMO-LUMO analysis of p-acetylbenzonitrile using quantum chemical calculation. J. Mol. Struct. 2013, 1038, 134-144. [CrossRef]

47. Prashanth, J.; Ramesh, G.; Naik, J.L.; Ojha, J.K.; Reddy, B.V. Molecular geometry, NBO analysis, Hyperpolarizability and HOMO-LUMO energies of 2-azido-1-phenylethanone using Quantum chemical calculations. Mater. Today Proc. 2016, 3, 3761-3769. [CrossRef]

48. Al-Omary, F.A.M.; Mary, Y.S.; Panicker, C.Y.; El-Emam, A.A.; Al-Swaidan, I.A.; Al-Saadi, A.A.; Alsenoy, C.V. Spectroscopic investigations, NBO, HOMO-LUMO, NLO analysis molecular docking of 5-(adamantan-1-yl)-3anilinomethyl-2,3-dihydro-1,3,4-oxadiazole-2-thione, a potential bioactive agent. J. Mol. Struct. 2015, 1096, 1-14. [CrossRef]

49. Koparir, M.; Orek, C.; Koparir, P.; Sarac, K. Synthesis, experimental, theoretical characterization and biological activities of4-ethyl-5-(2-hydroxyphenyl)-2H-1,2,4-triazole-3(4H)-thione. Spectrochim. Acta, Part A 2013, 105, 522-531. [CrossRef]

50. Fleming, I. Frontier Orbitals and Organic Chemical Reactions; John Wiley \& Sons: New York, NY, USA, 1976.

51. Şahin, Z.S.; Kantar, G.K.; Şaşmaz, S.; Büyükgüngör, O. Synthesis, molecular structure, spectroscopic analysis, thermodynamic parameters and molecular modeling studies of (2-methoxyphenyl)oxalate. J. Mol. Struct. 2015, 1087, 104-112. [CrossRef]

52. Koopmans, T. Über die Zuordnung von Wellenfunktionen und Eigenwerten zu den Einzelnen Elektronen Eines Atoms. Physica 1934, 1, 104-113. [CrossRef] 
53. Pearson, R.G. Absolute electronegativity and hardness correlated with molecular orbital theory. Proc. Natl. Acad. Sci. USA. 1986, 83, 8440-8441. [CrossRef] [PubMed]

54. Ismail, M.F.; El-sayed, A.A. Synthesis and in-vitro antioxidant and antitumor evaluation of novel pyrazole-based heterocycles. J. Iran. Chem. Soc. 2019, 16, 921-937. [CrossRef]

55. Lissi, E.A.; Modak, B.; Torres, R.; Escobar, J.; Urzua, A. Total antioxidant potential of resinous exudates from Heliotropium species, and a comparison of the ABTS and DPPH methods. Free Radic. Res. 1999, 30, 471. [CrossRef] [PubMed]

56. Brand-Williams, W.; Cuvelier, M.E.; Berset, C. use of a free radical method to evaluate antioxidant activity. Lebensm. Wiss. Technol. 1995, 28, 25-30. [CrossRef]

57. Mensor, L.L.; Menezes, F.S.; Leitao, G.G.; Reis, A.S.; dos Santos, T.C.; Coube, C.S.; Leitão, S.G. Screening of Brazilian plant extracts for antioxidant activity by the use of DPPH free radical method. Phytother. Res. 2001, 15, 127-130. [CrossRef]

58. Frisch, M.J.; Trucks, G.W.; Schlegel, H.B.; Scuseria, G.E.; Robb, M.A.; Cheeseman, J.R.; Scalmani, G.; Barone, V.; Mennucci, B.; Petersson, G.A.; et al. Gaussian 09, Revision D.01; Gaussian Inc.: Wallingford, CT, USA, 2009.

59. Becke, A.D. Density-functional exchange-energy approximation with correct asymptotic behavior. Phys. Rev. A 1988, 38, 3098-3100. [CrossRef]

60. Lee, C.; Yang, W.; Parr, R.G. Development of the Colle-Salvetti correlation-energy formula into a functional of the electron density. Phys. Rev. B 1988, 37, 785-789. [CrossRef]

Sample Availability: Samples of the compounds are available from the authors.

(C) 2019 by the authors. Licensee MDPI, Basel, Switzerland. This article is an open access article distributed under the terms and conditions of the Creative Commons Attribution (CC BY) license (http://creativecommons.org/licenses/by/4.0/). 